\title{
THE VALUE OF HUMAN MILK COMPARED WITH OTHER FEEDS FOR PREMATURE INFANTS
}

\author{
BY \\ V. MARY CROSSE, EVELYN M. HICKMANS, BETTY E. HOWARTH and \\ JOAN AUBREY \\ From the Premature Baby Unit, Sorrento Maternity Hospital, Birmingham, and the Biochemical Department of the \\ Children's Hospital, Birmingham
}

(RECEIVED FOR PUBLICATION FEBRUARY 5, 1954)

The food for choice for premature babies is still a matter of much discussion. Some paediatricians believe that human milk is not ideal because of the low proportions of protein and mineral salts and the high proportion of fat. Jorpes, Magnusson and Wretlind (1946) reported better weight gains by adding hydrolysed protein to human milk. The addition of skimmed lactic acid milk to human milk has been suggested by Hess and Lundeen (1949). Other workers have obtained better rates of gain on half-skimmed dried cow's milk instead of human milk (Gordon, Levine and McNamara, 1947; Mackay and Levin, 1953). It has also been suggested that cow's milk is superior to human milk in preventing rickets in premature infants (von Sydow, 1946).

On the other hand it is known that the fat of human milk is better utilized than the fat of cow's milk (Gordon and McNamara, 1941) and the retention and utilization of the available protein is much higher in the premature baby than in larger babies (Gordon and Levine, 1944). In addition, it has been suggested that retrolental fibroplasia is less likely to develop among babies fed on human milk, and to quote Hepner and Krause (1952) 'this has influenced more paediatricians either to continue using, or to revert to using human milk for premature feeding'. These workers found $45 \%$ blind babies among 49 fed on a high electrolytic cow's milk diet and only $8 \%$ among 84 fed on human milk.

Ford (1949) reported a smaller initial loss and a more rapid return to birth weight among babies fed on human milk than among babies fed on three different cow's milk mixtures. Subsequent rates of gain were similar on all diets. All babies in his investigation were over $3 \frac{1}{2} \mathrm{lb}$. $(1,588 \mathrm{~g}$.) at birth.
When assessing the value of a diet it is customary to use the rate of gain in weight as the yard stick, but gain in weight varies with the degree of water retention and is not a reliable index of growth. This will be referred to later in this paper. In addition, it has not yet been proved that the maximum rate of growth is the optimum.

Young, Poyner-Wall, Humphreys, Finch and Broadbent (1950) working in the Sorrento Premature Baby Unit and the Birmingham Children's Hospital, studied the nutrition of premature babies by means of serum protein and haemoglobin levels as well as by weight. These workers found that the progress of babies weighing over $3 \frac{1}{2} \mathrm{lb}$. (1,588 g.) at birth was unaffected by the various diets used, provided sufficient calories were given, but they suggested that human milk and modified cow's milk with a low protein content similar to that of human milk might not supply sufficient protein for babies weighing less than $3 \frac{1}{2} \mathrm{lb}$. $(1,588 \mathrm{~g}$.) at birth and that the resulting malnutrition might lead to infection. Their trials included only 10 babies with birth weights less than $3 \mathrm{lb}$. $(1,361 \mathrm{~g}$.) and of the 134 babies the observations on whom were finally analysed, only five were fed on unmodified human milk. During the trials, 31 babies were excluded because of infection, but the diets of these babies were not indicated. One cannot therefore exclude the remote possibility that the diets which gave the least protection against infection gave the best final results because the more weakly babies had been eliminated by infection.

From practical experience of many types of diet used in the Premature Baby Unit at Sorrento, both the nursing and medical staff had the impression that babies fed on human milk not only gave less 
anxiety during the early days but also had less subsequent infection and a lower mortality rate. This impression had to be proved or disproved, and it was felt that if morbidity and mortality were studied in addition to serum protein and haemoglobin levels and weight, and if supervision could be continued until the age of 1 year, then the performance of babies fed on human milk could be more fairly compared with that of babies fed on other low- and on high-protein diets and the following questions might be answered: (1) Is there any evidence that unmodified human milk is an unsuitable food for small premature babies? (2) If unmodified human milk should not prove to be the most suitable, should additions be made to human milk or should cow's milk be used instead? (3) Even if the best results are obtained with human milk (alone or with additions) which cow's milk mixture is the best substitute when human milk is not available? (4) If a high-protein diet gives the best results, should part of the protein be hydrolysed?

It was in an attempt to answer these questions that the following investigation was begun. It originally included 164 babies with a birth weight under $4 \mathrm{lb}$. $(1,814 \mathrm{~g}$.). These babies were admitted to the Sorrento Premature Baby Unit from the City of Birmingham and the surrounding areas during the years 1948-1951. On admission, all babies weighing less than $4 \mathrm{lb}$. $(1,814 \mathrm{~g}$.) at birth were placed in half-pound birth-weight groups, and in each weight group were allocated in rotation to the five diets (Table 1) but babies were only finally included in the reports if they survived the first week of life. The exceptions were (1) babies with obvious congenital defects; (2) babies admitted after the first 12 hours of life because the exact birth weight was not known; (3) babies in the 3-4 $\mathrm{lb}$. $(1,361-1,814$ g.) group admitted from outside the City of Birmingham during the last 18 months of the investigation (the number of babies in this group was adequate if local babies only were included and this obviated long journeys to the follow-up clinic); (4) babies in the higher weight groups admitted during the last six months of the trials because a sufficient number had already been investigated.

Of the 164 babies originally included at the age of 1 week, the following had to be excluded at a later stage: (1) Three babies with late-presenting congenital defects (one hiatus hernia, one cystic lung and one hydrocephalus); (2) one baby whose total number of blood samples was insufficient owing to accidents to samples during testing or transit; (3) five babies who died during their stay in hospital, one death being due to atelectasis (17 days), two to pneumonia (17 days and 5 weeks), one to strangulated hernia (16 days) and one to meningitis (6 weeks). These deaths are included in the mortality

TABLE 1

DISTRIBUTION OF BABIES IN BIRTH-WEIGHT AND DIET GROUPS

\begin{tabular}{|c|c|c|c|c|c|c|c|c|c|c|c|c|c|c|c|c|c|}
\hline \multicolumn{3}{|c|}{ Birth Weight } & \multirow{2}{*}{$\begin{array}{c}\text { A. } \\
\text { Males }\end{array}$} & \multirow{2}{*}{$\begin{array}{l}\text { Human } \\
-\overline{\text { Females }}\end{array}$} & \multirow{2}{*}{$\frac{\text { Milk }}{\text { Total }}$} & \multicolumn{3}{|c|}{$\begin{array}{l}\text { B. Low-protein } \\
\text { Cow's Milk } \\
\text { Mixture } \\
\text { (Evaporated milk) }\end{array}$} & \multicolumn{3}{|c|}{$\begin{array}{l}\text { High-protein } \\
\text { Cow's Milk } \\
\text { Mixture (Half- } \\
\text { skimmed dried milk) }\end{array}$} & \multicolumn{3}{|c|}{$\begin{array}{l}\text { D. Human Milk } \\
\text { with Added } \\
\text { Protein }\end{array}$} & \multicolumn{3}{|c|}{$\begin{array}{l}\text { E. Low-protein } \\
\text { Cow's Milk } \\
\text { Mixture with } \\
\text { Added Protein }\end{array}$} \\
\hline g. & lb. & oz. & & & & Males & Females & Total & Males & Females & Total & Males & Females & Total & Males & Females & Total \\
\hline up to & $u_{2}$ to & $\begin{array}{l}\text { up to } \\
32\end{array}$ & - & 1 & 1 & - & - & - & - & - & - & - & - & - & - & - & - \\
\hline $\begin{array}{r}900- \\
1,140\end{array}$ & $\begin{array}{l}2 \text { to } \\
2 \frac{1}{2}\end{array}$ & $\frac{32}{40}$ & 2 & 2 & $\begin{array}{c}4 \\
(3 \\
\text { twins } \\
1 \text { trip- } \\
\text { let })\end{array}$ & 1 & 1 & $\begin{array}{c}2 \\
(1 \\
\text { twin })\end{array}$ & 1 & 2 & $\begin{array}{c}3 \\
(1 \\
\text { twin) }\end{array}$ & 1 & 1 & 2 & 1 & 1 & 2 \\
\hline $\begin{array}{l}1,140- \\
1,360\end{array}$ & 21 to & $\begin{array}{l}40 \\
-48\end{array}$ & 2 & 8 & $\begin{array}{c}10 \\
\text { twin) }\end{array}$ & 4 & 7 & $\begin{array}{l}11 \\
(5 \\
\text { twins })\end{array}$ & 1 & 7 & 8 & 2 & 4 & $\begin{array}{c}6 \\
\quad 4 \\
\text { twins, } \\
1 \text { trip- } \\
\text { let) }\end{array}$ & 2 & 4 & $\begin{array}{c}6 \\
(2 \\
\text { twins })\end{array}$ \\
\hline $\begin{array}{l}1,360- \\
1,590\end{array}$ & $\begin{array}{l}3 \text { to } \\
3 \frac{1}{2}\end{array}$ & $\frac{48}{56}$ & 5 & 7 & $\begin{array}{c}12 \\
(3 \\
\text { twins, } \\
1 \text { trip- } \\
\text { let) }\end{array}$ & 4 & 6 & $\begin{array}{l}10 \\
(3 \\
\text { twins })\end{array}$ & 9 & 5 & \begin{tabular}{|l}
14 \\
$(8$ \\
twins, \\
1 trip- \\
let $)$
\end{tabular} & 9 & 3 & $\begin{array}{l}12 \\
\text { twins) }\end{array}$ & 4 & 7 & $\begin{array}{c}11 \\
(5 \\
\text { twins) }\end{array}$ \\
\hline $\begin{array}{l}1,590 \\
1,820\end{array}$ & 4 to & $\begin{array}{l}56 \\
64\end{array}$ & 4 & 4 & $\begin{array}{c}8 \\
(1 \\
\text { twin) }\end{array}$ & 6 & 4 & $\begin{array}{c}10 \\
(5 \\
\text { twins) }\end{array}$ & 5 & 4 & $\begin{array}{c}9 \\
(3 \\
\text { twins })\end{array}$ & 2 & 2 & $\begin{array}{c}4 \\
(2 \\
\text { twins })\end{array}$ & 5 & 2 & $\begin{array}{c}7 \\
(2 \\
\text { twins })\end{array}$ \\
\hline $\begin{array}{l}\text { Total } \\
4 \text { lb. (1 }\end{array}$ & $0 \mathrm{~g}$.) an & ad less & 13 & 22 & 35 & 15 & 18 & 33 & 16 & 18 & 34 & 14 & 10 & 24 & 12 & 14 & 26 \\
\hline
\end{tabular}


rates of the various diet groups, and the cases of infection are included in the infection rates; (4) three babies for whom it was necessary to change the diet, one infant weighing $1 \mathrm{lb} .12 \mathrm{oz}$. (795 g.) did not tolerate the addition of hydrolysed casein to human milk and two were changed to human milk after having developed severe infections on the lowprotein cow's milk mixture. The two with infections are included in the infection rates for the various diets. The remaining 152 babies were grouped according to diet and birth weight as shown in Table 1.

\section{Records}

Weight. Babies were weighed naked on admission (to check birth weight) and thereafter twice weekly.

Haemoglobin. Levels were estimated weekly using the Evans electro-selenium photo-electric colorimeter.

Serum Proteins. Levels were determined weekly on serum from venous blood collected from a scalp vein.

Infections. All infections, major and minor, were recorded.

Progresis after Discharge from Unit. The infants were seen regularly at a special follow-up clinic at Sorrento Maternity Hospital.

Mortality. All infants were traced to the age of 1 year or to death if this occurred before the age of 1 year. All deaths were known and recorded.

In addition, these babies were included in two other investigations which were also in progress at the time, namely on rickets and retrolental fibroplasia. Because of these investigations the wrists of all babies were radiographed at the age of 3 months, and the fundi of all babies were examined at regular intervals.

\section{Diets and Methods of Feeding}

Type of Diet. Five diets were used in this investigation and details are shown in Table 2. In order to ensure that calories would not be lost from inability to utilize high percentages of cow's milk fat, the fat content was kept at $1.6 \%$ in the three cow's milk mixtures. The caloric values were all adjusted to 20 per oz. by varying the amount of sugar in the cow's milk mixtures and by slight dilution of the human milk before adding the hydrolysed casein.

Babies fed on human milk (diet A) could be compared with babies fed on human milk reinforced with hydrolysed casein (diet D), a low-protein cow's milk mixture (diet B), a cow's milk mixture with a high content of protein (diet $\mathrm{C}$ ) and a high-protein cow's milk mixture in which part of the protein was hydrolysed (diet E).

Method of Feeding. The feeding routine was the same for all babies and was that normally employed in the Unit. There was an initial starvation period during which nothing was given by mouth. Feeding began on the third day for babies who weighed 3-4 lb. $(1,361$ $1,814 \mathrm{~g}$.) at birth and on the fourth day for those under $3 \mathrm{lb}$. $(1,361 \mathrm{~g}$.). All the diets were given diluted at first, but full strength was reached by the seventh day in the case of the larger babies and by the tenth day in the case of the smaller babies. The volume of fluid given each day for the first ten days was calculated according to the formula

$\frac{1}{4}$ oz. $\times$ day of life $\times$ birth weight in lb.

Between the tenth and fourteenth days of life the daily

TABLE 2

COMPOSITION OF DIETS USED IN INVESTIGATION

\begin{tabular}{|c|c|c|c|c|c|c|c|c|}
\hline & Name of Diet & Code & Composition of Diet & $\begin{array}{l}\text { Protein } \\
(\%)\end{array}$ & $\begin{array}{c}\text { Fat } \\
(\%)\end{array}$ & $\begin{array}{l}\text { Carbo- } \\
\text { hydrate } \\
(\%)\end{array}$ & $\begin{array}{l}\text { Mineral } \\
\text { Salts } \\
(\%)\end{array}$ & $\begin{array}{l}\text { Calories per Fl. Oz. } \\
\text { of Mixture ( } 28.4 \mathrm{ml} \text {.) }\end{array}$ \\
\hline $\mathbf{A}$ & Human milk & 0 & Human milk & $1 \cdot 5$ & $4 \cdot 0$ & $7 \cdot 5$ & $0 \cdot 2$ & 20 \\
\hline B & $\begin{array}{l}\text { Low-protein } \\
\text { cow's milk mixture } \\
\text { (evaporated milk) }\end{array}$ & $0^{-\cdot-\cdot \cdot \cdot-0}$ & $\begin{array}{l}\text { Evaporated full-cream cow's milk } \\
1 \text { in } 5 \text { with } 1 \text { drachm(1) sugar to } \\
\text { every } 1 \frac{1}{2} \text { oz. of mixture }\end{array}$ & $1 \cdot 7$ & $1 \cdot 6$ & $10 \cdot 3$ & $0 \cdot 4$ & 20 \\
\hline C & $\begin{array}{l}\text { High-protein } \\
\text { cow's milk mixture } \\
\text { (half-skimmed } \\
\text { dried) }\end{array}$ & $0----0$ & $\begin{array}{l}\text { Half-skimmed dried cow's milk } \\
1 \text { in } 10 \text { with } 1 \text { drachm( } 2) \text { sugar to } \\
\text { every } 2 \text { oz. of mixture }\end{array}$ & $3 \cdot 0$ & $1 \cdot 6$ & $10 \cdot 7$ & 0.7 & 20 \\
\hline D & $\begin{array}{l}\text { Human milk with } \\
\text { added protein }\end{array}$ & $x \longrightarrow x$ & $\begin{array}{l}\text { Human milk with sweetened casein } \\
\text { hydrolysate ('casydrol' benger-genato- } \\
\text { san) } 7 \cdot 75 \text { g.(3) to } 8 \cdot 75 \text { fl. oz. of } \\
\text { human milk and } 1 \cdot 25 \mathrm{fl} \text { oz. of water }\end{array}$ & $3 \cdot 3$ & $3 \cdot 5$ & $6 \cdot 6$ & $0 \cdot 4$ & 20 \\
\hline $\mathbf{E}$ & $\begin{array}{l}\text { Low-protein } \\
\text { cow's milk mixture } \\
\text { with added protein }\end{array}$ & $x---x$ & $\begin{array}{l}\text { Evaporated full-cream cow's milk } \\
1 \text { in } 6 \text { with } 2 \text { drachm(4) of sweetened } \\
\text { casein hydrolysate and } 1 \text { drachm of } \\
\text { sugar to every } 2 \mathrm{oz} \text {. of mixture }\end{array}$ & $2 \cdot 95$ & $1 \cdot 6$ & $9 \cdot 5$ & $0 \cdot 4$ & 20 \\
\hline
\end{tabular}

(1) $4 \mathrm{~g}$. sugar to $43 \mathrm{ml}$. mixture.

(2) 4 g. sugar to $57 \mathrm{ml}$. mixture.

(3) $7.75 \mathrm{~g}$. casein hydrolysate to $248 \mathrm{ml}$. human milk and $35 \mathrm{ml}$. water.

(4) $2 \mathrm{~g}$. casein hydrolysate and $4 \mathrm{~g}$. sugar to $57 \mathrm{ml}$. mixture. 
volume was increased to $3 \mathrm{oz}$. per lb. (200 ml. per $\mathrm{kg}$.). After the birth weight had been passed, the quantity was calculated on actual weight instead of the birth weight.

Supplements. All babies had the same supplements, i.e., Vitamin $B$, $\frac{1}{2}$ tablet 'benerva' (0.5 mg. $B_{1}$ and $B_{2}$ and $7.5 \mathrm{mg}$. nicotinic acid) daily as soon as feeding was started. Vitamin C, $10 \mathrm{mg}$. on the first day of feeding, increasing (daily) by $10 \mathrm{mg}$. up to maximum of $100 \mathrm{mg}$. daily. Vitamin D, 50,000 I.U. ('calciferol'), was given at the age of 2 weeks and again at 1 month of age. At the age of 2 months (or before discharge if this occurred before the age of 2 months) 500,000 I.U. were given. Vitamin A, 15,000 I.U., was given daily from the age of 1 week. Calcium and phosphorus, syrup of calcium lactophosphate $(7 \mathrm{minims}$ per $\mathrm{lb}$. of body weight daily $\equiv 1 \mathrm{ml}$. per $1,100 \mathrm{~g}$. body weight), was given from the fourteenth day. Iron, ferric ammonium citrate, $2 \frac{1}{2}$ grains $(0 \cdot 1,625 \mathrm{~g}$.), was given once daily from the age of 1 month and this dose was gradually increased to 5 grains daily ( $2 \frac{1}{2}$ grains twice daily).

Change of Diet. When the diet to be given at home was different from that given in the Unit the changeover began in all cases when the baby reached the weight of $4 \frac{1}{2} \mathrm{lb}$. $(2,042 \mathrm{~g}$.) and was completed in about seven or eight days.

\section{Clinical Observations during Stay in Hospital}

Time Taken to Return to Birth Weight. Because babies in each weight group had a comparable period of initial starvation and were then given the same dilutions of the various diets, the average number of days taken to regain the birth weight by the babies in each weight group could be compared for the different diets (Table 3).

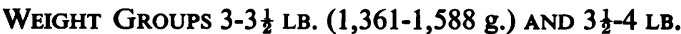
$(1,588-1,814$ G.). In these groups the time taken to regain the birth weight was much the same in all diet groups. Babies fed on half-skimmed dried milk (diet C) and evaporated milk with added protein (diet E) took a slightly shorter time and babies on evaporated milk (diet B) and human milk with added protein (diet D) a slightly longer time than those fed on human milk.

WeIGHT Group $2 \frac{1}{2}-3$ LB. (1,134-1,361 g.). In this group unfortunately there were very few babies, but the worst results were obtained when protein was added to human milk (diet D) and to evaporated milk (diet E). This was probably due to intolerance of the added casein hydrolysate. One baby weighing $1 \mathrm{lb} .12 \mathrm{oz}$. (795 g.) at birth who was originally included in group $D$ vomited persistently each time casein hydrolysate was added but did well on human milk alone and had to be excluded from the trials because of this change of diet. In the weight group $2-2 \frac{1}{2} \mathrm{lb}$. $(907-1,134 \mathrm{~g}$.) the three babies on half-skimmed dried milk (diet C) appeared to do better than the four babies fed on human milk, but not so well as the $1 \mathrm{lb} .14 \mathrm{oz}$. (852 g.) baby also fed on human milk. Babies fed on evaporated milk (diet B) regained their birth weights in about the same time as those on human milk. Evaporated milk (diet B) and half-skimmed dried milk (diet C) were both well tolerated.

Subsequent Gain in Weight. The time taken to regain the birth weight is obviously closely related to the

TABLE 3

AVERAGE NUMBER OF DAYS TAKEN TO REGAIN BIRTH WEIGHT

\begin{tabular}{|c|c|c|c|c|c|c|c|c|c|c|}
\hline \multirow{2}{*}{ Birth Weight } & \multicolumn{2}{|c|}{ A. Human Milk } & \multicolumn{2}{|c|}{$\begin{array}{l}\text { B. Low-protein } \\
\text { Cow's Milk Mixture } \\
\text { (Evaporated Milk) }\end{array}$} & \multicolumn{2}{|c|}{$\begin{array}{c}\text { C. High-protein } \\
\text { Cow's Milk Mixture } \\
\text { (Dried Half-skimmed } \\
\text { Milk) }\end{array}$} & \multicolumn{2}{|c|}{$\begin{array}{l}\text { D. Human Milk } \\
\text { with added } \\
\text { Protein }\end{array}$} & \multicolumn{2}{|c|}{$\begin{array}{c}\text { E. Low-protein } \\
\text { Cow's Milk Mixture } \\
\text { with Added } \\
\text { Protein }\end{array}$} \\
\hline & $\begin{array}{l}\text { Average } \\
\text { Birth } \\
\text { Weight }\end{array}$ & $\begin{array}{l}\text { No. } \\
\text { of } \\
\text { Days }\end{array}$ & $\begin{array}{l}\text { Average } \\
\text { Birth } \\
\text { Weight }\end{array}$ & $\begin{array}{c}\text { No. } \\
\text { of } \\
\text { Days }\end{array}$ & $\begin{array}{l}\text { Average } \\
\text { Birth } \\
\text { Weight }\end{array}$ & $\begin{array}{c}\text { No. } \\
\text { of } \\
\text { Days }\end{array}$ & $\begin{array}{l}\text { Average } \\
\text { Birth } \\
\text { Weight }\end{array}$ & $\begin{array}{l}\text { No. } \\
\text { Days }\end{array}$ & $\begin{array}{l}\text { Average } \\
\text { Birth } \\
\text { Weight }\end{array}$ & $\begin{array}{l}\text { No. } \\
\text { of } \\
\text { Days }\end{array}$ \\
\hline up to $2 \mathrm{lb}$. $(900 \mathrm{~g})$. & $\begin{array}{l}1 \text { lb. } 14 \text { oz. } \\
(852 \mathrm{g.}) \\
\quad(1 \text { baby) }\end{array}$ & $15 \cdot 0$ & 一 & 一 & 一 & - & 一 & - & 一 & - \\
\hline 2 lb. -21 lb. & $\begin{array}{l}2 \text { lb. } 5 \mathrm{oz} . \\
(1,049 \mathrm{~g}) \\
(4 \text { babies })\end{array}$ & $17 \cdot 75$ & $\begin{array}{l}2 \text { lb. 61 oz. } \\
\text { (1,090 g.) } \\
(2 \text { babies) }\end{array}$ & $18 \cdot 0$ & $\begin{array}{l}2 \text { lb. } 61 \text { oz. } \\
(1,090 \mathrm{~g} .) \\
(3 \text { babies })\end{array}$ & $15 \cdot 6$ & $\begin{array}{l}2 \text { lb. } 31 \text { oz. } \\
\text { (1,006 g.) } \\
\text { (2 babies) }\end{array}$ & $19 \cdot 0$ & $\begin{array}{l}2 \text { lb. } 21 \text { oz. } \\
\text { (979 g.) } \\
\text { (2 babies) }\end{array}$ & $21 \cdot 0$ \\
\hline $\begin{array}{l}\text { 2t } 1 b .-3 \text { lb. } \\
(1,140-1,360 \text { g. })\end{array}$ & $\begin{array}{l}2 \text { lb. } 12 \frac{1}{2} \text { oz. } \\
(1,260 \text { g. })\end{array}$ & $15 \cdot 6$ & $\begin{array}{c}2 \text { lb. } 12 \ddagger \text { oz. }) \\
(1,255 \text { g.) }\end{array}$ & $20 \cdot 0$ & 2 lb. $13 \mathrm{oz}$. & 14 & $\begin{array}{l}2 \text { lb. } 14 \frac{s}{\text { oz. }} \\
(1,325 \mathrm{~g} .)\end{array}$ & $22 \cdot 3$ & 2 lb. 12 oz. & $14 \cdot 2$ \\
\hline $\begin{array}{l}\text { Total up to } 3 \mathrm{lb} . \\
(1,360 \mathrm{~g} .)\end{array}$ & $2 \underset{(1,180 \mathrm{~g} .)}{9 \frac{1}{2}} \mathrm{oz}$. & $16 \cdot 1$ & $\begin{array}{l}2 \text { lb. } 11 \frac{1}{2} \text { oz. } \\
(1,234 \mathrm{~g} .)\end{array}$ & $19 \cdot 7$ & 2 lb. $11 \mathrm{oz}$. & $14 \cdot 4$ & 2 lb. $12 \mathrm{oz}$. & $21 \cdot 5$ & $2 \underset{(1,191 \mathrm{~g} .)}{1 \mathrm{~b} .} 10 \mathrm{oz}$. & $15 \cdot 9$ \\
\hline $\begin{array}{l}3 \text { lb. }-31 \text { lb. } \\
(1,360-1,590 \text { g.) }\end{array}$ & 3 lb. 4 oz. & $14 \cdot 75$ & 3 lb. 5 oz. & $16 \cdot 7$ & $\begin{array}{c}3 \text { lb. } 41 \text { oz. } \\
(1,488 \text { g. })\end{array}$ & $13 \cdot 5$ & 3 lb. 4 oz. & $15 \cdot 0$ & $3 \underset{(1,474 \mathrm{~g} .)}{4}$ & $13 \cdot 5$ \\
\hline $\begin{array}{l}3 \mathrm{z} \\
(1,5,-4 \text { lb. }\end{array}$ & 3 lb. 13 oz. & $12 \cdot 0$ & $\begin{array}{l}3 \text { lb. } 12 t \text { oz. } \\
\left(1,710_{\mathrm{g} .}\right)\end{array}$ & $14 \cdot 4$ & 3 lb. 11 oz. & $11 \cdot 2$ & 3 lb. 11 oz. & $13 \cdot 2$ & $\begin{array}{l}3 \text { lb. } 11 \frac{1}{2} \text { oz. } \\
(1,687 \mathrm{~g} .)\end{array}$ & $12 \cdot 0$ \\
\hline $\begin{array}{l}\text { Total over } 3 \text { lb. } \\
(1,360 \text { g. })\end{array}$ & 3 lb. $7 \frac{1}{2} \mathrm{oz}$. & $13 \cdot 6$ & $3 \underset{(1,602 \mathrm{~g} .)}{81}$ & $15 \cdot 6$ & 3 lb. 7 oz. & $12 \cdot 9$ & 3 lb. 8 oz. & $14 \cdot 5$ & 3 lb. 8 oz. & $12 \cdot 9$ \\
\hline
\end{tabular}


condition of the baby at and shortly after birth. Weight gain must therefore also be examined at a later stage. Subsequent gain in weight is dependent to some degree on the actual weight and was therefore estimated by comparing the average time taken by babies in each birth weight group to increase their weights from the upper limit of their weight group to $4 \frac{1}{2} \mathrm{lb}$. (2,042 g.). (At this weight it was sometimes necessary to change the diet in preparation for discharge from hospital.)

Table 4 shows the average number of days taken to pass through each weight range under consideration for all weight groups up to $3 \frac{1}{2} \mathrm{lb}$. (1,588 g.). Babies weighing $3 \frac{1}{2}-4 \mathrm{lb}$. (1,588-1,814 g.) had too short a period on their original diet to make it worth while comparing them in this way, but their progress is discussed later.

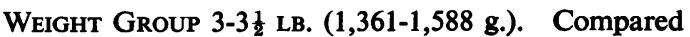
with babies fed on human milk, babies fed on halfskimmed milk (diet C) took a shorter time, and babies on evaporated milk with added protein (diet E) a longer time, while those on evaporated milk (diet B) and human milk with added protein (diet $D)$ took approximately the same time. (One baby who died from infection was excluded from diet D.)

Weight Group $2 \frac{1}{2}-3$ LB. (1,134-1,361 g.). Again babies on half-skimmed milk (diet $C$ ) took the shortest time. Those fed on evaporated milk (diet B) and human milk with added protein (diet D) were slowest (one baby with pneumonia was excluded from diet B). Evaporated milk with added protein (diet E) gave results comparable to human milk.

Weight Group LeSS THAN $2 \frac{1}{2}$ LB. $(1,134$ g.). It would appear that the best results were obtained with halfskimmed dried milk (diet $C$ ) and the worst with evaporated milk with added protein (diet $\mathrm{E})$.
If one baby who died from infection had not been excluded from the group fed on human milk with added protein (diet D) the results on this diet would have been worse. This whole group is discussed more fully in relation to the weight curves.

Weight Gains Showed Graphically. To show the weight gains graphically the actual weights of each individual infant in each weight group were plotted, and from these graphs the average weight at any time of all cases in each diet group could be found. The average weight curves for each diet are shown in Fig. 1. The average birth weight of each diet group has been made to coincide with the same weight on an average foetal or in utero weight curve (Fig. 2, Crosse, 1952). The curves do not correspond exactly with the figures shown in Tables 3 and 4 because they are average curves; in addition the diet was changed as each individual baby reached a weight of $4 \frac{1}{2} \mathrm{lb}$. $(2,042 \mathrm{~g}$.) and not when the average curve reached this weight. The approximate age at which the change of food (if any) took place was as follows:

\begin{tabular}{|c|c|}
\hline Weight Group & Age of Baby. \\
\hline $\begin{array}{l}\text { Under } 2 \frac{1 b}{2}(1,134 \text { g. }) \\
21-3 \text { lb. }(1,134-1,361 \text { g. }) \\
3-3 \frac{1}{\mathrm{~g}} \text { lb. }(1,361-1,588 \text { g. }) \\
3 \frac{1}{2}-4 \text { lb. } \quad(1,588-1,814 \text { g. })\end{array}$ & $\begin{array}{l}8-12 \text { weeks } \\
7-10 \quad ", \\
5-7 \quad ", \\
4-5 \quad "\end{array}$ \\
\hline
\end{tabular}

The average curves show in a general way the facts deduced from Tables 3 and 4.

Weight Group $3 \frac{1}{2}-4$ LB. $(1,588-1,814$ g.). Once the birth weight had been regained, the average weight curves ran roughly parallel to the average weight curve of the foetus in utero, irrespective of the diet (Fig. 1A). But it should be remembered that the curves for babies fed on

TABLE 4

AVERAGE NUMBER OF DAYS TAKEN BY EACH WEIGHT GROUP TO REACH $4 \frac{1}{2}$ LB. FROM A STANDARD WEIGHT FOR EACH GROUP

\begin{tabular}{|c|c|c|c|c|c|c|c|c|c|c|c|}
\hline \multirow[t]{2}{*}{ Birth Weight } & \multirow{2}{*}{$\begin{array}{c}\text { Weight Range } \\
\text { Used }\end{array}$} & \multicolumn{2}{|c|}{ A. Breast Milk } & \multicolumn{2}{|c|}{$\begin{array}{l}\text { B. Low-protein } \\
\text { Cow's Milk } \\
\text { Mixture } \\
\text { (Evaporated Milk) }\end{array}$} & \multicolumn{2}{|c|}{$\begin{array}{l}\text { C. High-protein } \\
\text { Cow's Milk } \\
\text { Mixture } \\
\text { (Half-dried Milk) }\end{array}$} & \multicolumn{2}{|c|}{$\begin{array}{l}\text { D. Breast Milk } \\
\text { with Added } \\
\text { Protein }\end{array}$} & \multicolumn{2}{|c|}{$\begin{array}{l}\text { E. Low-protein } \\
\text { Cow's Milk } \\
\text { Mixture with } \\
\text { Added Protein }\end{array}$} \\
\hline & & $\begin{array}{l}\text { Average } \\
\text { Birth } \\
\text { Weight }\end{array}$ & $\begin{array}{l}\text { Average } \\
\text { No. of } \\
\text { Days }\end{array}$ & $\begin{array}{l}\text { Average } \\
\text { Birth } \\
\text { Weight }\end{array}$ & $\begin{array}{l}\text { Average } \\
\text { No. of } \\
\text { Days }\end{array}$ & $\begin{array}{l}\text { Average } \\
\text { Birth } \\
\text { Weight }\end{array}$ & $\begin{array}{l}\text { Average } \\
\text { No. of } \\
\text { Days }\end{array}$ & $\begin{array}{l}\text { Average } \\
\text { Birth } \\
\text { Weight }\end{array}$ & $\begin{array}{l}\text { Average } \\
\text { No. of } \\
\text { Days }\end{array}$ & $\begin{array}{l}\text { Average } \\
\text { Bjirth } \\
\text { Weight }\end{array}$ & $\begin{array}{l}\text { Average } \\
\text { No. of } \\
\text { Days }\end{array}$ \\
\hline $\begin{array}{l}2 \text { lb. }-2 \frac{1}{2} \text { lb. } \\
(900-1,140 \mathrm{~g} .)\end{array}$ & $\begin{array}{l}2 \frac{1}{2} 1 \mathrm{~b} .-4 \frac{1}{2} \mathrm{lb} . \\
(1,140-2,040 \mathrm{~g} .)\end{array}$ & $\mid \begin{array}{c}2 \mathrm{lb} . \\
5 \mathrm{oz} . \\
(4 \mathrm{babies}) \\
(1,049 \mathrm{~g} .)\end{array}$ & $44 \cdot 5$ & $\begin{array}{c}2 \mathrm{lb} . \\
6 \frac{1}{2} \mathrm{oz} . \\
(2 \mathrm{babies}) \\
(1,090 \mathrm{~g} .)\end{array}$ & $43 \cdot 75$ & $\begin{array}{c}2 \mathrm{lb} . \\
6 t \text { oz. } \\
(3 \mathrm{babies}) \\
(1,048 \mathrm{~g} .)\end{array}$ & $33 \cdot 3$ & $\begin{array}{c}2 \text { lb. } \\
3 \frac{1}{2} \text { oz. } \\
(2 \text { babies }) \\
(1,006 \mathrm{~g} .)\end{array}$ & $\begin{array}{l}37 \cdot 5 \\
1 \text { infec- } \\
\text { tion } \\
\text { death }\end{array}$ & $\mid \begin{array}{c}2 \mathrm{lb} . \\
2 \frac{1}{2} \mathrm{oz} . \\
(2 \text { babies }) \\
(977 \mathrm{~g} .)\end{array}$ & $51 \cdot 0$ \\
\hline $\begin{array}{l}21 \text { lb.-3 lb. } \\
(1,140-1,360 \mathrm{~g} .)\end{array}$ & $\begin{array}{c}3 \text { lb. }-4 \frac{1}{2} \text { lb. } \\
(1,360-2,040 \text { g. })\end{array}$ & $\begin{array}{c}2 \text { lb. } \\
12 \frac{1}{2} \text { oz. } \\
\text { (10 } \\
\text { babies) } \\
(1,262 \mathrm{~g} .)\end{array}$ & $30 \cdot 3$ & $\begin{array}{c}2 \mathrm{lb} . \\
12 \text { oz. } \\
\text { (11 } \\
\text { babies) } \\
(1,262 \mathrm{gg})\end{array}$ & $\mid \begin{array}{c}32 \cdot 5 \\
1 \text { infec- } \\
\text { tion } \\
\text { excluded }\end{array}$ & $\begin{array}{c}2 \mathrm{lb} . \\
13 \mathrm{oz} . \\
(8 \mathrm{babies}) \\
(1,276 \mathrm{~g} .)\end{array}$ & $29 \cdot 0$ & $\begin{array}{c}2 \mathrm{lb} . \\
14 \mathrm{da} \text { oz. } \\
(6 \mathrm{babies}) \\
(1,324 \mathrm{~g} .)\end{array}$ & $34 \cdot 7$ & $\begin{array}{c}2 \text { lb. } \\
12 \frac{1}{2} \text { oz. } \\
(6 \text { babies }) \\
(1,262 \mathrm{~g} .)\end{array}$ & $30 \cdot 5$ \\
\hline $\begin{array}{l}3 \text { lb. }-3 \frac{1}{2} 1 b . \\
1,360-1,590 \text { g.) }\end{array}$ & $\begin{array}{c}\left.3 \frac{1}{\mathrm{~g}} \mathrm{lb} .-4 \frac{1}{2} \mathrm{lb} .\right) \\
(1,590-2,040 \mathrm{~g} .)\end{array}$ & $\begin{array}{c}3 \mathrm{lb} . \\
4 \mathrm{oz} . \\
\text { (12 } \\
\text { babies) } \\
(1,474 \mathrm{~g} .)\end{array}$ & $17 \cdot 0$ & $\begin{array}{c}3 \mathrm{lb} . \\
5 \mathrm{oz} . \\
(10 \\
\text { (babies) } \\
(1,503 \mathrm{~g} .)\end{array}$ & $16 \cdot 8$ & $\begin{array}{c}3 \mathrm{lb} . \\
4 \frac{1}{\mathrm{~g}} \mathrm{oz} . \\
\text { (14 } \\
\text { babies) } \\
\text { (1,488 g.) }\end{array}$ & $15 \cdot 0$ & $\begin{array}{c}3 \mathrm{lb} . \\
4 \mathrm{oz} . \\
(12 \\
\text { babies }) \\
(1,474 \mathrm{~g} .)\end{array}$ & $\begin{array}{c}16 \cdot 8 \\
1 \text { infec- } \\
\text { tion } \\
\text { death }\end{array}$ & $\begin{array}{c}3 \mathrm{lb} . \\
4 \mathrm{oz} . \\
(11 \\
\text { babies) } \\
(1,474 \mathrm{~g} .)\end{array}$ & $19 \cdot 0$ \\
\hline
\end{tabular}



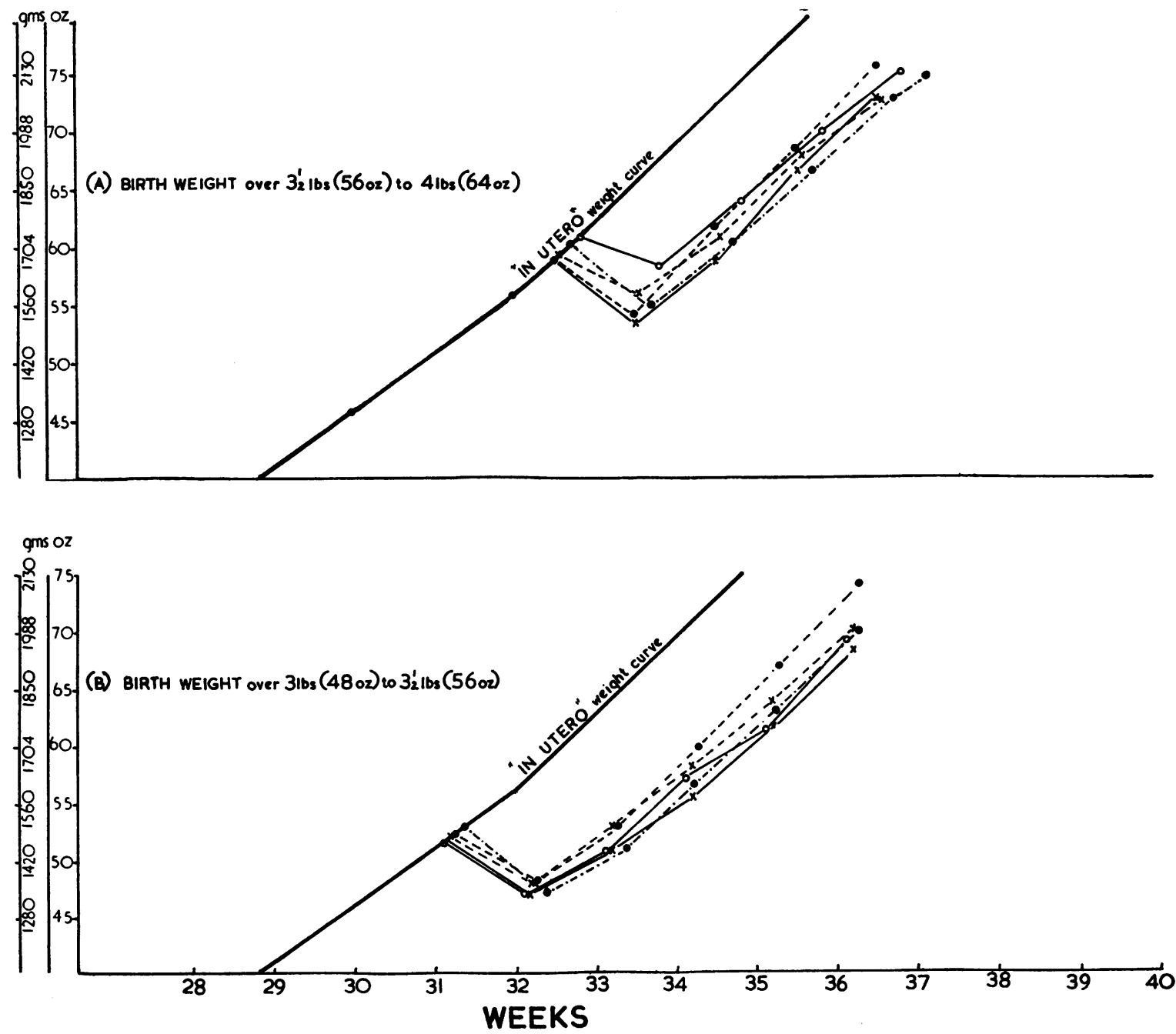

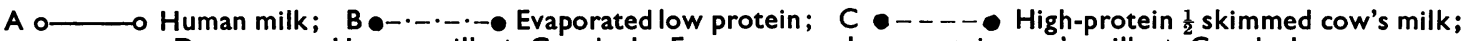
D $x \longrightarrow x$ Human milk + Casydrol; E X - - - x Low-protein cow's milk + Casydrol.

Fig. 1.-Average weight curves for each diet.

evaporated milk (diet B) and human milk with added protein (diet D) would not have been so good if one case which developed pneumonia had not been excluded from each (the case on human milk with added protein died). Some of the babies in this weight group were slightly oedematous during the first few days of life but whatever the diet very few developed any subsequent oedema unless they became anaemic.

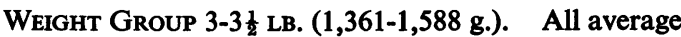
curves were approximately parallel to the in utero curve irrespective of the diet, but babies on half-skimmed dried milk (diet $\mathrm{C}$ ) gained a little more rapidly than those on the other diets. One death from infection had been excluded from the group fed on human milk with added protein (diet D).

WeIGHT GrouP $2 \frac{1}{2}-3$ LB. (1,134-1,361 g.). The average curves still tended to run parallel to the in utero curve but at a slightly lower level, especially if the time taken to regain the birth weight had been prolonged. This finding seems to indicate the importance of using an easily digested and well tolerated diet during the first few weeks of life. After regaining the birth weight babies fed on half-skimmed dried milk (diet C) and evaporated milk with added protein (diet E) showed 

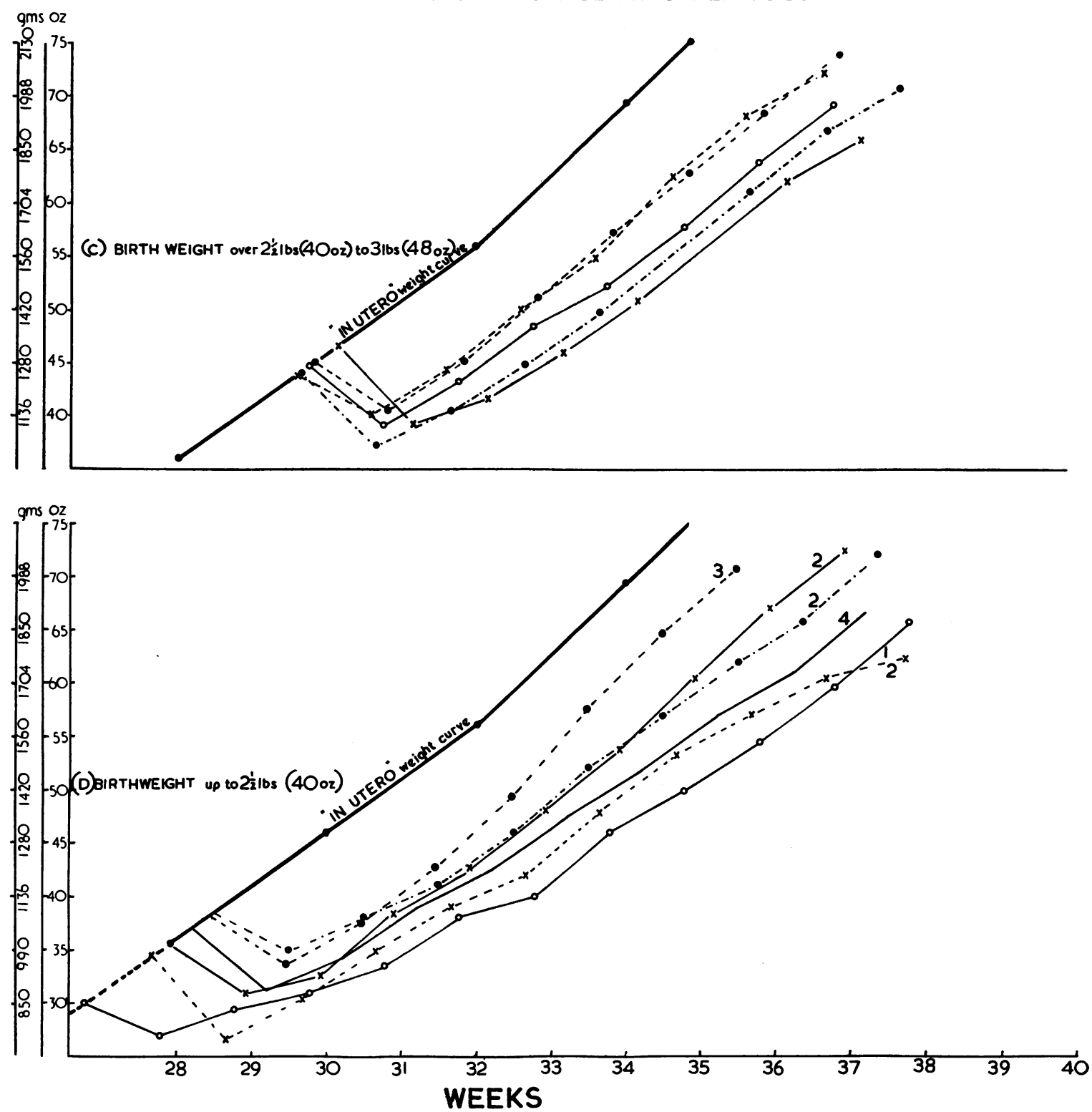

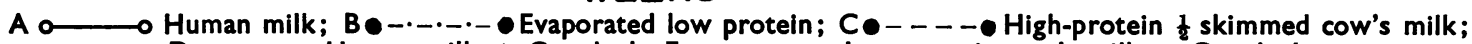
D $\mathrm{x} \longrightarrow \mathrm{x}$ Human milk + Casydrol; E x - - - $\mathrm{x}$ Low-protein cow's milk + Casydrol.

slightly better curves and those on evaporated milk (diet B) and human milk with added protein (diet B) showed slightly worse curves than those fed on human milk. The curve for diet $B$ would have been worse if a case of pneumonia had not been excluded because of the necessity to substitute human milk during the illness.

At this point it should be noted that the majority of babies in the two weight groups $2 \frac{1}{2}-3 \mathrm{lb}$. (1,134-1,361 g.) and $3-3 \frac{1}{2} \mathrm{lb}$. (1,361-1,588 g.) showed early oedema which subsided rapidly, but among the group fed on half-skimmed dried milk (diet C) slight oedema usually developed again at the approximate age of 3 to 4 weeks (one or two weeks after reaching the full strength formula as set out in Table 2). The oedema was not usually obvious unless babies were carefully examined. It lasted for several weeks and must have accounted for at least part of the extra gain in weight among babies on this diet. This tendency for oedema to develop on half-skimmed cow's milk formula has already been reported by Hepner and Krause (1952). They 
noticed that babies changed from human milk to this type of cow's milk diet developed thickening and hardening of the skin and in some cases frank pitting oedema of

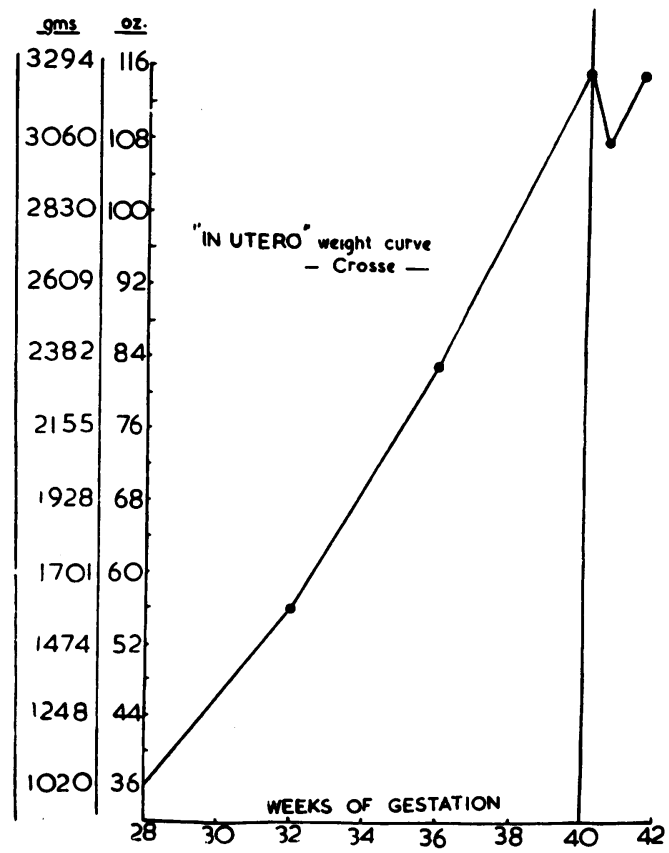

FIG. 2.-Average ' in utero' weight curve (Crosse).

the scalp and ankles, and that a diuresis and a loss of weight occurred with disappearance of the oedema on a return to human milk, followed after a few days by a resumption of the original daily rate of gain. These workers also changed the diet of two babies aged 1 month from cow's milk to human milk and noted a temporary loss of weight accompanied by a decrease in the smoothness of the contours of the body and thinning of the skin. When these two babies were returned to their original cow's milk diet a sharp increase of weight occurred with thickening and increased firmness of the skin. These experiments have been repeated by one of us (V.M.C.) and we have found that all extra weight and oedema can be lost and regained by changing babies from half-skimmed dried milk (diet C) to human milk and vice versa. Gordon, Levine, Wheatley and Marples (1937) also observed excessive fluid retention with cow's milk formulae. Premature babies are known to have a limited capacity to excrete electrolytes (Young, Hallum and McCance, 1941), so this oedema was probably due to the inability of the immature kidneys of these smaller babies to cope with the high electrolyte content of halfskimmed dried milk.

WeIGHT GRouP UNDER $2 \frac{1}{2}$ LB. $(1,134 \mathrm{~g}$.). The babies in this group were too few to give significant average curves for each diet. Nevertheless curves have been plotted for what they are worth, with the number of babies in brackets against each curve. The three babies on half-skimmed dried milk (diet $\mathrm{C}$ ) gave an average weight curve slightly better than the in utero curve but these babies all developed a slight degree of oedema which lasted for several weeks, and their gain was partially due to excessive water retention. The curve for babies on half-skimmed dried milk (diet C) was closely followed by that for two babies on human milk with added protein (diet $D$ ), but the baby who persistently vomited on diet $D$, and another baby who died of infection had been excluded. The two babies on evaporated milk with added protein (diet E) gave the worst curve. One baby weighing $1 \mathrm{lb} .14 \mathrm{oz}$. (852 g.) at birth (curve shown separately in Fig. 1D) did well on human milk: so did a baby weighing $1 \mathrm{lb} .12 \mathrm{oz}$. (795 g.) at birth who could not tolerate human milk with added protein (diet $D$ ) but the latter could not be included in the reports of this investigation because of the change of diet.

Even if large numbers of these small babies were available for trial, it would still be difficult to assess the value of different diets, because their survival and progress depend so much more on such factors as development of the lungs, the presence or absence of birth injury, and other complications.

The following points emerged from a study of the rate of gain while the infants were in hospital.

(1) In all weight-groups, babies fed on halfskimmed dried milk (diet C) made the most rapid progress, both in regaining the birth weight and in the subsequent rate of gain. This diet was well tolerated, even by the smaller babies.

(2) Evaporated milk was well tolerated, but generally speaking babies fed on this diet gained the least rapidly.

(3) The addition of casein hydrolysate to human milk and to evaporated milk (diet B) was not well tolerated by babies under $2 \frac{1}{2} \mathrm{lb}$. $(1,134 \mathrm{~g}$.) at birth during early life. Later this addition was well tolerated but made no striking difference to the rate of gain.

(4) The difference between the rate of gain among babies fed on half-skimmed dried milk (diet C) and on human milk was at least partially due to the difference in the hydration of the babies in the two groups, babies on human milk retaining less water than those on diet $\mathbf{C}$.

(5) In the light of these trials, there is no doubt in the minds of the nursing and medical staff at Sorrento that human milk is the diet which is best tolerated by the very small infants (under $2 \frac{1}{2} \mathrm{lb}$. $(1,134 \mathrm{~g}$.) at birth) during the first few weeks of life. It also appears to be the best diet for any premature baby whose tolerance to food has been reduced by infection.

Anaemia and Transfusions. The degree of anaemia developed by premature babies on different diets is 
TABLE 5

BABIES REQUIRING TRANSFUSION

\begin{tabular}{|c|c|c|c|c|c|c|c|c|c|c|}
\hline \multirow[t]{2}{*}{ Birth Weight } & \multicolumn{2}{|c|}{ A. Human Milk } & \multicolumn{2}{|c|}{$\begin{array}{l}\text { B. Low-protein } \\
\text { Cow's Milk } \\
\text { (Evaporated Milk) }\end{array}$} & \multicolumn{2}{|c|}{$\begin{array}{c}\text { C. High-protein } \\
\text { Cow's Milk Mixture } \\
\text { (Half Skimmed Dried } \\
\text { Milk) }\end{array}$} & \multicolumn{2}{|c|}{$\begin{array}{r}\text { D. Human Milk } \\
\text { with Added Protein }\end{array}$} & \multicolumn{2}{|c|}{$\begin{array}{l}\text { E. Low-protein } \\
\text { Cow's Milk Mixture } \\
\text { with Added Protein }\end{array}$} \\
\hline & $\underset{\text { Group }}{\text { Babies in }}$ & $\begin{array}{c}\text { Babies } \\
\text { Transfused }\end{array}$ & $\begin{array}{c}\text { Babies in } \\
\text { Group }\end{array}$ & $\begin{array}{c}\text { Babies } \\
\text { Transfused }\end{array}$ & $\begin{array}{c}\text { Babies in } \\
\text { Group }\end{array}$ & $\begin{array}{c}\text { Babies } \\
\text { Transfused }\end{array}$ & $\begin{array}{l}\text { Babies in } \\
\text { Group }\end{array}$ & $\begin{array}{c}\text { Babies } \\
\text { Transfused }\end{array}$ & $\underset{\text { Group }}{\text { Babies in }}$ & $\begin{array}{c}\text { Babies } \\
\text { Transfused }\end{array}$ \\
\hline $\begin{array}{l}2 \text { lb. }-2 \frac{1}{2} \text { lb. } \\
(900-1,140 \text { g. })\end{array}$ & 4 & 2 & 2 & 2 & 3 & 2 & 2 & - & 2 & 2 \\
\hline $\begin{array}{l}2 \frac{1}{2} \\
(1,140-3 \quad l b \\
(1,360 \text { g.) }\end{array}$ & 10 & 6 & 11 & 11 & 8 & 4 & 6 & 5 & 6 & 2 \\
\hline $\begin{array}{r}\text { Total } 2 \text { lb. }-3 \text { lb. } \\
\quad(900-1,360 \text { g. }\end{array}$ & 14 & $8=57 \%$ & 13 & $13=100 \%$ & 11 & $6=54 \%$ & 8 & $5=63 \%$ & 8 & $4=50 \%$ \\
\hline $\begin{array}{l}3 \text { lb. }-3 \frac{1}{2} \text { lb. } \\
(1,360-1,600 \text { g.) }\end{array}$ & 12 & 2 & 10 & 3 & 14 & 4 & 12 & 1 & 11 & 3 \\
\hline $3 \frac{1}{\mathrm{z}}$ lb. -4 lb. & 8 & 1 & 10 & 2 & 9 & 1 & 4 & - & 7 & - \\
\hline $\begin{array}{l}\text { Total } \underset{(1,360-1,810}{3} \text { g. })\end{array}$ & 20 & $3=15 \%$ & 20 & $5=25 \%$ & 23 & $5=22 \%$ & 16 & $1=6 \%$ & 18 & $3=17 \%$ \\
\hline Grand Total & 34 & $11=32 \%$ & 33 & $18=55 \%$ & 34 & $11=32 \%$ & 24 & $6=25 \%$ & 26 & $7=27 \%$ \\
\hline
\end{tabular}

another way of assessing the value of the diets. Weekly haemoglobin estimations were made on all babies on the same colorimeter, and the time of introduction of iron into the diet was the same for all babies. Indications for transfusion were : (1) a haemoglobin level of less than $9.0 \mathrm{~g}$. at any time during the first 10 weeks of life; (2) a haemoglobin level less than $10 \mathrm{~g}$. and rapidly falling, in a baby under 10 weeks of age who was due for discharge from hospital.

Babies were transfused with packed cells $(10 \mathrm{ml}$. per lb. body weight) by the scalp vein route, and the number of those who required this treatment is shown in Table 5. In all weight groups, babies fed on evaporated milk (diet B) required the highest proportion of transfusions. There was little difference between the proportion of babies transfused among the three high-protein diet groups (diets C, $D$, and $E$ ) or between them and the group fed on human milk.

Judging by haemoglobin levels it would appear that evaporated milk (diet B) was not a good food for premature babies.
Incidence of Infection during Stay in Premature Baby Unit. Every infection which occurred among the babies under review was recorded, however mild; and these infections have been divided into two classes.
(1) Minor Sticky eyes
Mild skin infections
Thrush
Moist cord (no definite infec-
tion)
Slight nasal discharge
(2) Major Otitis media

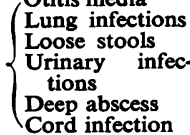

Table 6 shows the proportion of infected babies in each diet and weight group. Babies with more than one infection were included among those with major infections if one of their infections belonged to this class.

In order to obtain the true proportions of infected babies in each group it was necessary to include five babies, who were excluded from the rest of the investigation, i.e., three who died of infection during the trials (all fed on human milk with added protein, diet $\mathrm{D}$,) and two who became so ill with pneumonia that it was necessary to change their diet to human milk (both were originally on evaporated milk, diet B.)

TABLE 6

PERCENTAGE IN EACH GROUP INFECTED DURING STAY IN PREMATURE BABY UNIT

\begin{tabular}{|c|c|c|c|c|c|c|c|c|c|c|}
\hline \multirow[b]{2}{*}{ Birth Weight } & \multicolumn{2}{|c|}{ A. Human Milk } & \multicolumn{2}{|c|}{$\begin{array}{l}\text { B. Low-protein } \\
\text { Cow's Milk Mixture } \\
\text { (Evaporated Milk) }\end{array}$} & \multicolumn{2}{|c|}{$\begin{array}{l}\text { C. High-protein } \\
\text { Cow's Milk Mixture } \\
\text { (Half-skimmed Milk) }\end{array}$} & \multicolumn{2}{|c|}{$\begin{array}{l}\text { D. Human Milk } \\
\text { with Added Protein }\end{array}$} & \multicolumn{2}{|c|}{$\begin{array}{l}\text { E. Low-protein } \\
\text { Cow's Milk Mixture } \\
\text { with Added Protein }\end{array}$} \\
\hline & Minor & Major & Minor & Major & Minor & Major & Minor & Major & Minor & Major \\
\hline $2 \begin{array}{lll}\mathrm{lb} .-3 & \mathrm{lb} . \\
(900-1,360 \mathrm{~g} .)\end{array}$ & 43 & 36 & 21 & 50 & 18 & 36 & 38 & $\begin{array}{c}50 \\
\text { (1 death) }\end{array}$ & 50 & 25 \\
\hline 3 lb. $-4 \mathrm{lb} .1,360-1,810$ g. $)$ & 35 & Nil & 40 & 5 & 31 & 4 & 19 & $\begin{array}{c}31 \\
\text { (2 deaths) }\end{array}$ & 33 & 22 \\
\hline
\end{tabular}


Because the numbers are small the babies have been considered in two groups, those under $3 \mathrm{lb}$. $(1,361 \mathrm{~g}$.$) and those between 3$ and $4 \mathrm{lb}$. $(1,361$ and 1,814 g.) and because the major infections are most likely to be affected by the diet the following remarks will refer to the proportions who developed major infections.

In the 2-3 lb. (937-1,361 g.) group, the highest proportions of infected babies were found among those fed on evaporated milk (diet B) and human milk with added protein (diet D) (one death on diet D) and the lowest on evaporated milk with added protein (diet E). Babies fed on human milk and half-skimmed dried milk (diet C) suffered equally from severe infections.

In the 3-4 lb. (1,361-1,814 g.) group the highest proportions of infected babies were among those fed on human milk with added protein (diet D; two babies on this diet died of infections) and on evaporated milk with added protein (diet $E$ ). The lowest proportions were found among those fed on human milk.

Considering all weight groups together, the least infection occurred among babies fed on human milk, followed closely by those fed on half-skimmed dried milk (diet C). The greatest amount of infection occurred among babies fed on human milk with added protein (diet $\mathrm{D}$; three babies in this diet group died from infections). Babies fed on evaporated milk (diet B) and evaporated milk with added protein (diet E) had almost as high an infection rate as those fed on human milk with added protein (diet D).

Mortality during Stay in Premature Baby Unit. Babies who died after being allotted to a diet group are shown in their correct weight and diet group in
Table 7. Neither of the deaths among babies fed on human milk could reasonably be related to the diet. The three deaths among babies fed on human milk with added protein (diet D) were all due to infection. There were no deaths among babies fed on the other three diets during their stay in hospital, although there were two serious cases of pneumonia among the groups fed on evaporated milk (diet B).

\section{Follow-up of Regular Attenders to the Age of 6 Months}

Babies included in this investigation were followed up at a special out-patients' clinic. Some could not attend the clinic because of the distance involved (up to 120 miles), and several failed to attend in spite of repeated invitations. The following results are limited to those babies seen regularly every month up to 6 months of age. At each attendance, weight, haemoglobin and infections were recorded and blood was taken for chemical examination. Advice on feeding was given.

Feeding after Discharge from Hospital. Few babies went home completely breast-fed. (This was before the addition of mothers' quarters to the Unit.) Of the 12 babies able to be breast fed, six had been on low-protein diets (three on human milk and three on evaporated milk, diet B), and six on high-protein diets (one on half-skimmed dried milk, diet $\mathrm{C}$, three on human milk with added protein, diet $D$, and two on evaporated milk with added protein, diet E). For the purpose of the follow-up these babies were grouped together irrespective of their diet while in hospital. All babies unable to be breast-fed after discharge were changed to the diet they would have at home when they

TABLE 7

MORTALITY DURING STAY IN PREMATURE BABY UNIT

\begin{tabular}{|c|c|c|c|c|c|}
\hline Birth Weight & A. Human Milk & $\begin{array}{l}\text { B. Low-protein } \\
\text { Cow's Milk } \\
\text { (Evaporated Milk) }\end{array}$ & $\begin{array}{l}\text { C. High-protein } \\
\text { Cow's Milk Mixture } \\
\text { (Half-skimmed dried } \\
\text { Milk) }\end{array}$ & $\begin{array}{l}\text { D. Human Milk } \\
\text { with Added Protein }\end{array}$ & $\begin{array}{l}\text { E. Low-protein } \\
\text { Cow's Milk Mixture } \\
\text { with Added Protein }\end{array}$ \\
\hline Up to 2 lb. (900 g.) & - & 一 & - & 一 & 一 \\
\hline $2-2 \frac{1}{2}$ lb. $(900-1,130$ g.) & - & - & 一 & $\begin{array}{l}1 \text { death at } 6 \text { weeks } \\
\text { (Bact. coli meningitis) }\end{array}$ & - \\
\hline $2 \frac{1}{2}-3$ lb. $(1,130-1,360$ g. $)$ & $\begin{array}{l}\text { * } 1 \text { died at } 16 \text { days } \\
\text { (strangulated hernia) } \\
\text { * } 1 \text { died at } 17 \text { days } \\
\text { (atelectasis only) }\end{array}$ & 一 & - & 一 & - \\
\hline $3-3 \frac{1}{2}$ lb. $(1,360-1,590$ g. $)$ & - & - & 一 & $\begin{array}{l}1 \text { death at } 17 \text { days } \\
\text { (pneumonia) }\end{array}$ & - \\
\hline 31-4 lb. $(1,590-1,820$ g. $)$ & 一 & 一 & - & $\begin{array}{l}1 \text { death at } 35 \text { days } \\
\text { (? pneumonia } \\
\text { no P.M.) }\end{array}$ & - \\
\hline
\end{tabular}

* Deaths not attributable to method of feeding. 
TABLE 8

SIX MONTHS FOLLOW-UP OF REGULAR ATTENDERS

\begin{tabular}{|c|c|c|c|c|c|}
\hline $\begin{array}{l}\text { Diet from Weight } \\
\text { of } 4 \frac{\mathrm{g}}{\mathrm{lb}}(2,040 \mathrm{~g} .)\end{array}$ & I. Breast-fed & $\begin{array}{l}\text { II. New Low-protein } \\
\text { Cow's Milk (Full- }\end{array}$ & \multicolumn{3}{|c|}{$\begin{array}{l}\text { III. New High-protein Cow's Milk } \\
\text { Mixture (Half-skimmed Dried Milk) }\end{array}$} \\
\hline $\begin{array}{l}\text { Diet until weight of } 4 \frac{1}{2} \mathrm{lb} . \\
(2,040 \mathrm{~g} .)\end{array}$ & $\begin{array}{ccc}3 & \text { Diet } & \mathbf{A} \\
3 & \text { " } & \mathbf{B} \\
1 & \text { " } & \mathbf{C} \\
3 & " & \mathbf{D} \\
\mathbf{2} & \text { " } & \mathbf{E}\end{array}$ & $\begin{array}{l}\text { Low-protein Cow's } \\
\text { Milk Mixture } \\
\text { (Diet B) }\end{array}$ & $\begin{array}{l}\text { High-protein Cow's } \\
\text { Milk Mixture } \\
\text { (33 Diet C) } \\
\text { (24 Diet E) }\end{array}$ & $\begin{array}{l}\text { Breast Milk } \\
\text { (Diet A) }\end{array}$ & $\begin{array}{l}\text { Breast Milk with } \\
\text { added Protein } \\
\text { (Diet D) }\end{array}$ \\
\hline $\begin{array}{l}\text { No. originally in each new } \\
\text { group }\end{array}$ & 12 & 30 & 57 & 32 & 21 \\
\hline $\begin{array}{l}\text { No. followed regularly in } \\
\text { clinic until } 6 \text { months }\end{array}$ & $10=83 \%$ & $17=57 \%$ & $38=67 \%$ & $25=78 \%$ & $15=71 \%$ \\
\hline $\begin{array}{l}\text { Average birth weight of those } \\
\text { followed }\end{array}$ & $\begin{array}{l}3 \text { lb. } 6 \mathrm{oz} . \\
(1,531 \mathrm{~g} .)\end{array}$ & 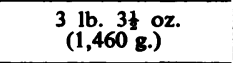 & $\begin{array}{l}3 \text { lb. } 21 \text { oz. } \\
(1,426 \mathrm{~g} .)\end{array}$ & 3 lb. $1 \frac{1}{2}$ oz. & 3 lb. $2 \mathrm{gz}$. \\
\hline $\begin{array}{l}\text { Average weight at } 6 \text { months } \\
\text { of those followed }\end{array}$ & $\begin{array}{l}\left.14 \mathrm{lb}_{(6,455} 3 \frac{1}{2} \mathrm{~g} .\right) \\
\text { (6) }\end{array}$ & $\begin{array}{l}12 \text { lb. } 10 \mathrm{oz} . \\
(5,732 \mathrm{~g})\end{array}$ & $\begin{array}{l}13 \mathrm{lb} . \\
(5,916 \mathrm{~g} .)\end{array}$ & $\begin{array}{l}13 \text { lb. } 2 \text { oz. } \\
(5,859 \mathrm{~g} .)\end{array}$ & $\begin{array}{l}13 \text { lb. } 91 \text { oz. } \\
(6,072 \mathrm{~g} .)\end{array}$ \\
\hline $\begin{array}{l}\text { Average haemoglobin level at } \\
6 \text { months of those fol- } \\
\text { lowed }\end{array}$ & $11 \cdot 7 \mathrm{~g}$ & $10.9 \mathrm{~g}$ & $10.0 \mathrm{~g}$ & $11 \cdot 4 \mathrm{~g}$ & $11 \cdot 2 \mathrm{~g}$. \\
\hline $\begin{array}{l}\text { Major infections after dis- } \\
\text { charge in those followed }\end{array}$ & Nil & $\left.\begin{array}{l}2 \text { chickenpox } \\
1 \text { diarrhoea }\end{array}\right\} 3$ & $\left.\begin{array}{l}4 \text { diarrhoea } \\
2 \text { whooping cough }\end{array}\right\} 6$ & $\left.\begin{array}{l}1 \text { Chickenpox } \\
2 \text { otitis media } \\
2 \text { bronchitis } \\
2 \text { diarrhoea }\end{array}\right\} 7$ & Bronchitis 1 \\
\hline $\begin{array}{l}\text { Deaths among babies fol- } \\
\text { lowed }\end{array}$ & Nil & Nil & $\begin{array}{l}2 \text { whooping cough } \\
2 \text { unknown cause } \\
1 \text { diarrhoea }\end{array}$ & Nil & Nil \\
\hline
\end{tabular}

reached a weight of $4 \frac{1}{2} \quad$ lb. $(2,042$ g.). Those previously fed on evaporated milk (diet B) were changed to another relatively low-protein cow's milk mixture, i.e., 1 in 12 full-cream dried milk mixture with 1 drachm $(4 \mathrm{~g}$.) of sugar to every $2 \mathrm{oz}$. (56 ml.) of the mixture (protein $2 \cdot 2 \%$, fat $2 \cdot 2 \%$, sugar $9 \cdot 2 \%$, calories 20 per oz.). The remaining babies who had been fed on the high-protein diets (33 on diet C, 21 on diet D, and 24 on diet E) and the remaining 32 babies who had been fed previously on human milk were given a new high-protein cow's milk mixture, i.e., half-skimmed dried milk 1 in 8 with 1 drachm ( $4 \mathrm{~g}$.) of sugar to every $3 \mathrm{oz}$. $(85 \mathrm{ml}$.) of the mixture (protein $3 \cdot 8 \%$, fat $2 \cdot 1 \%$, sugar $9 \cdot 5 \%$, calories 21 per oz.). Apart from the groups originally fed on human milk, those who had been on the low-protein diet continued on another lowprotein diet while those who had been on the three high-protein diets continued on another highprotein diet. This will be seen in Table 8.

Clinical Observations at 6 Months of Age. Table 8 sets out the findings at the age of 6 months.

Weight. Babies who were breast fed after discharge from hospital had a heavier average weight than any other group, even taking into account their slightly greater average birth weight. Of the remaining groups babies always fed on a low-protein cow's milk mixture did rather worse than all others.
Haemoglobin LeVels. Babies who had had some breast milk, either in the Unit or after discharge, had a higher average level of haemoglobin than babies always fed on cow's milk.

MAJOR INFECTIONS. There had been no infection among the 12 breast-fed babies but three out of 30 of those fed on the low-protein cow's milk mixture and seven out of 32 of those fed on the high-protein cow's milk mixture had suffered from major infections.

DEATHS. The only deaths had occurred among the group always fed on high-protein diets (before and after discharge). In two cases the cause was unknown but the other three were all due to infections. There were no deaths among the 12 breastfed babies, whereas five out of 110 infants fed on cow's milk had died. The breast-fed group was very small and these figures could not be considered significant. But in this connexion one of us (Crosse, 1952) has already shown the much greater risk of mortality from the age of 1 to 6 months among premature babies fed on cow's milk than among those fed on human milk.

Rickets. Some of the babies in those feeding trials were included in a rickets investigation which covered 227 infants. The wrists were radiographed at the age of 3 months. Minimal signs of rickets were found in 15 of the 109 babies fed entirely on 
human milk and in 30 out of 118 babies fed entirely on cow's milk. No infant showed clinical signs of rickets and all radiographs were normal by the age of 6 months. All children had been given the supplements already described.

Retrolental Fibroplasia. Five babies included in these feeding trials developed retrolental fibroplasia. All had received oxygen for periods varying from 18 to 30 days. One of these babies had originally been fed on human milk, one on human milk with added protein (diet D) and two on evaporated milk with added protein (diet E). The fundi were normal in all cases until two or three weeks after changing to half-skimmed dried milk (diet $C$ ), and oedema had occurred in all these cases at the time that the first signs appeared.

\section{Follow-up to Age of 1 Year}

As only about two-thirds of the babies under investigation had been followed up regularly until the age of 6 months, it was felt that all of them should be traced at the age of 1 year to discover the final mortality rate in each group. This was done from the '1-year-old report' cards returned by the parents, and for those who failed to return the card, through the local health authority concerned.

Table 9 shows that there were still no deaths among the 12 infants sent home completely breast fed, whereas 10 out of the total 140 infants fed on cow's milk had died before the age of 1 year.

\section{Observations on the Serum Protein Levels}

Blood specimens were taken from a scalp vein if possible at weekly intervals. Total protein was estimated using a micro-Kjeldahl digestion with $\mathrm{H}_{2} \mathrm{SO}_{4}-\mathrm{CuSO}_{4}$ mixture, adding selenium oxide after partial digestion, followed by steam distillation (Broadbent and Finch, 1950). Correction was made for the non-protein-nitrogen values determined on the same specimens. Albumin was estimated by the same method on the filtrate after precipitating globulin with $22 \cdot 2 \%$ sodium sulphate at $38^{\circ} \mathrm{C}$.

The values of the serum proteins (total, albumin and globulin) for the first 12 weeks of life for each child were plotted separately. They showed the same wide scatter as was found by Young et al. (1950) working in the same laboratory and are not shown in this report. The averages of the curves for each weight group on the various diets are shown in Fig. 3 together with the levels as determined on normal full-term infants (Poyner-Wall and Finch, 1950).

The babies over $2 \frac{1}{2} \mathrm{lb}$. $(1,134 \mathrm{~g}$.) birth weight will be considered first (Fig. 3, A.B.C.).

Total Proteins. The average curves show that the smaller and less mature the babies, the lower were the levels of serum total protein during the first week of life and for approximately the first three months of life, being well below the average levels for normal full-term infants. This may be related to the immaturity of the liver where many fractions of the serum proteins are formed, among them albumin and globulin. The total protein levels fell for some six or eight weeks, the fall being greater and more prolonged in the smaller babies than in the bigger babies, whatever food was given. This fall is more or less parallel with the fall of total protein levels shown by normal full-term infants, but at a lower level. It may possibly be explained as a normal physiological process. In the babies with a birth-weight over $3 \frac{1}{2} \mathrm{lb}$. $(1,588 \mathrm{~g}$.) the level of that of full-term normal children was attained at about 10 weeks of age, but this level was not reached by the babies with a birth weight of less than $3 \frac{1}{2} \mathrm{lb}$. $(1,588 \mathrm{~g}$.) in the 12 weeks of observation owing probably to the lower levels at birth.

The kind of food given seems to have made no

TABLE 9

FOLLOW-UP FROM DISCHARGE UNTIL AGE OF 1 YEAR (152 BABIES)

\begin{tabular}{|c|c|c|c|c|c|}
\hline Diet from $4 \mathrm{t}$ lb. & I. Breast Fed & $\begin{array}{l}\text { II. New Low-protein } \\
\text { Cow's Milk Mixture } \\
\text { (Full-cream Dried) }\end{array}$ & III. New High & $\begin{array}{l}\text { tein Cow's Milk } \\
\text { kimmed dried) }\end{array}$ & Mixture (Half- \\
\hline$\overline{\text { Diet until } 4 \frac{1}{\text { glb. }}(2,042 \text { g. }) \ldots}$ & $\begin{array}{ccc}3 & \text { Diet } & \mathbf{A} \\
3 & \text { ", } & \text { B } \\
1 & " & \text { C } \\
3 & " & \text { D } \\
2 & " & \text { E }\end{array}$ & Diet B & $\begin{array}{l}33 \text { diet } \mathrm{C} \\
24 \operatorname{diet} \mathrm{E}\end{array}$ & Diet A & Diet D \\
\hline $\begin{array}{l}\text { No. originally in each new } \\
\text { diet group }\end{array}$ & 12 & 30 & 57 & 32 & 21 \\
\hline No. dead at one year & None & 1 & 7 & 2 & None \\
\hline Causes of death & - & Unknown 1 & $\begin{array}{l}\text { Whooping cough } 2 \\
\text { Diarrhoea } 3 \\
\text { Unknown } 2\end{array}$ & $\begin{array}{ll}\text { Diarrhoea } & 1 \\
\text { Unknown } & 1\end{array}$ & - \\
\hline
\end{tabular}




\section{TOTAL PROTEINS}

\section{Normal Full-Term}

Infants
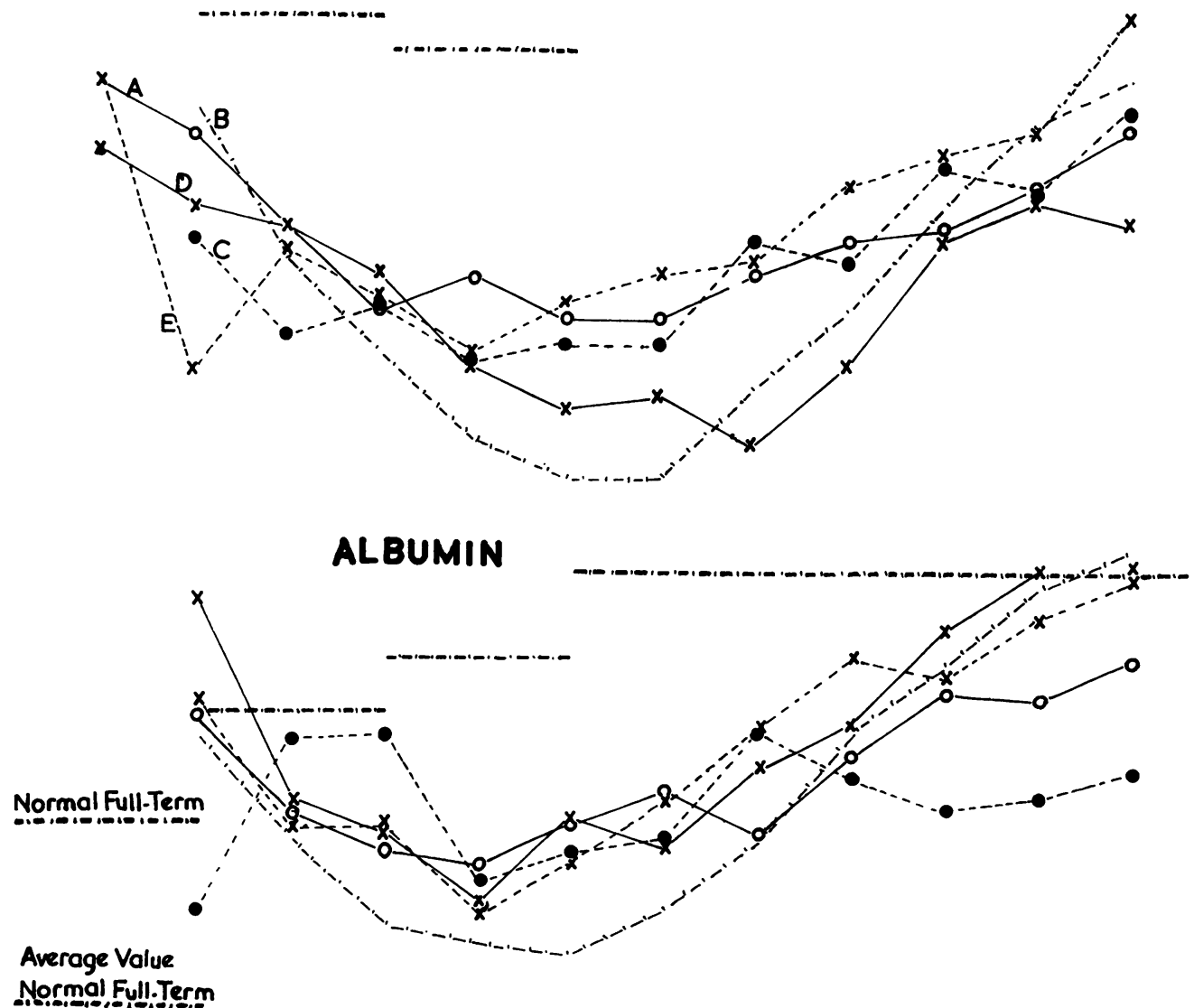

Normal Full.Term

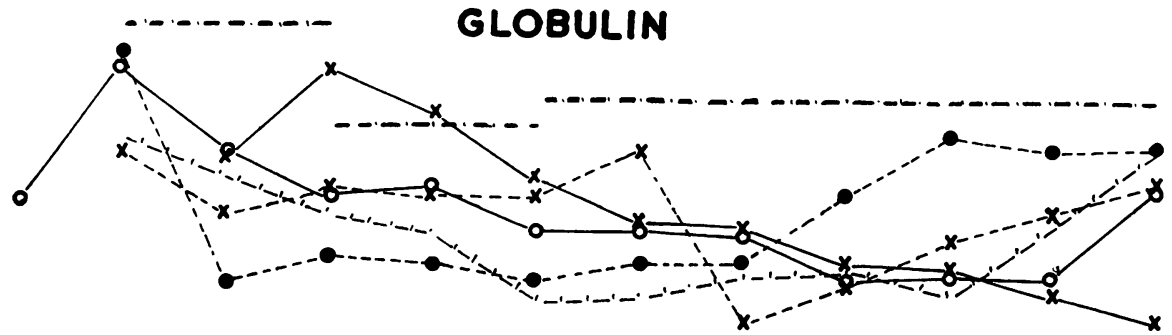

(A) $2 \frac{1}{2}-3 \mathrm{lb} .(1,134-1,361 \mathrm{~g}$.

○ـ Human milk; B-1-1-1-Evaporated low protein; C $-\ldots$ High-protein $\frac{1}{2}$ skimmed cow's milk; D $x \longrightarrow \times$ Human milk + Casydrol; E X - - - x Low-protein cow's milk + Casydrol.

Fig. 3.-Values for serum protein levels for each birth-weight group. 

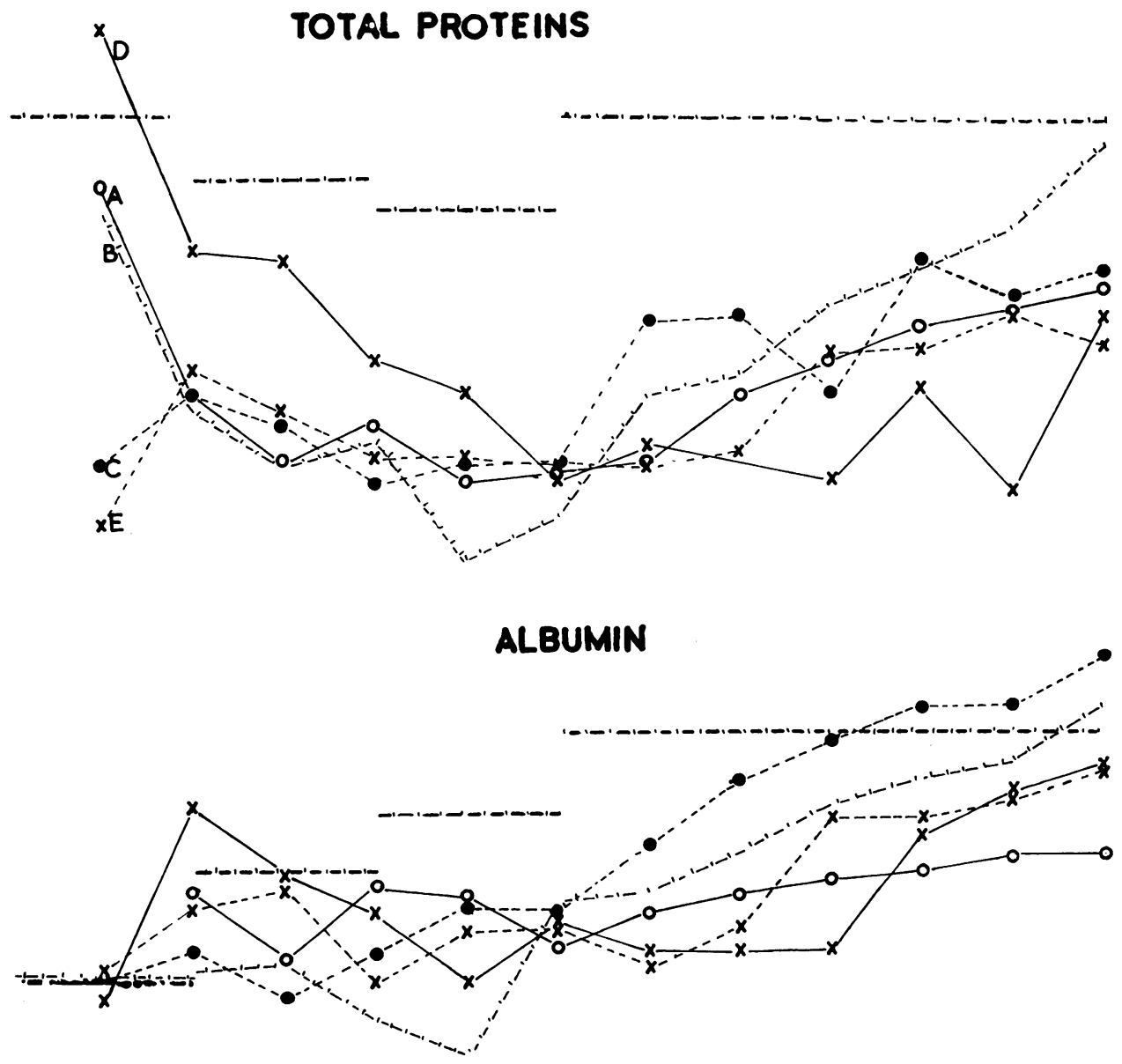

GLOBULIN

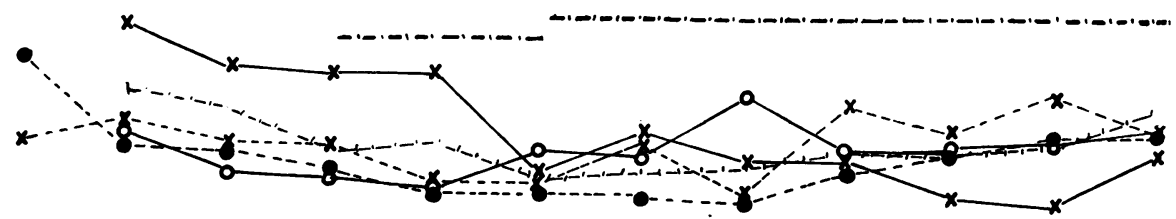

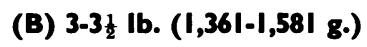

Fig. 3. 

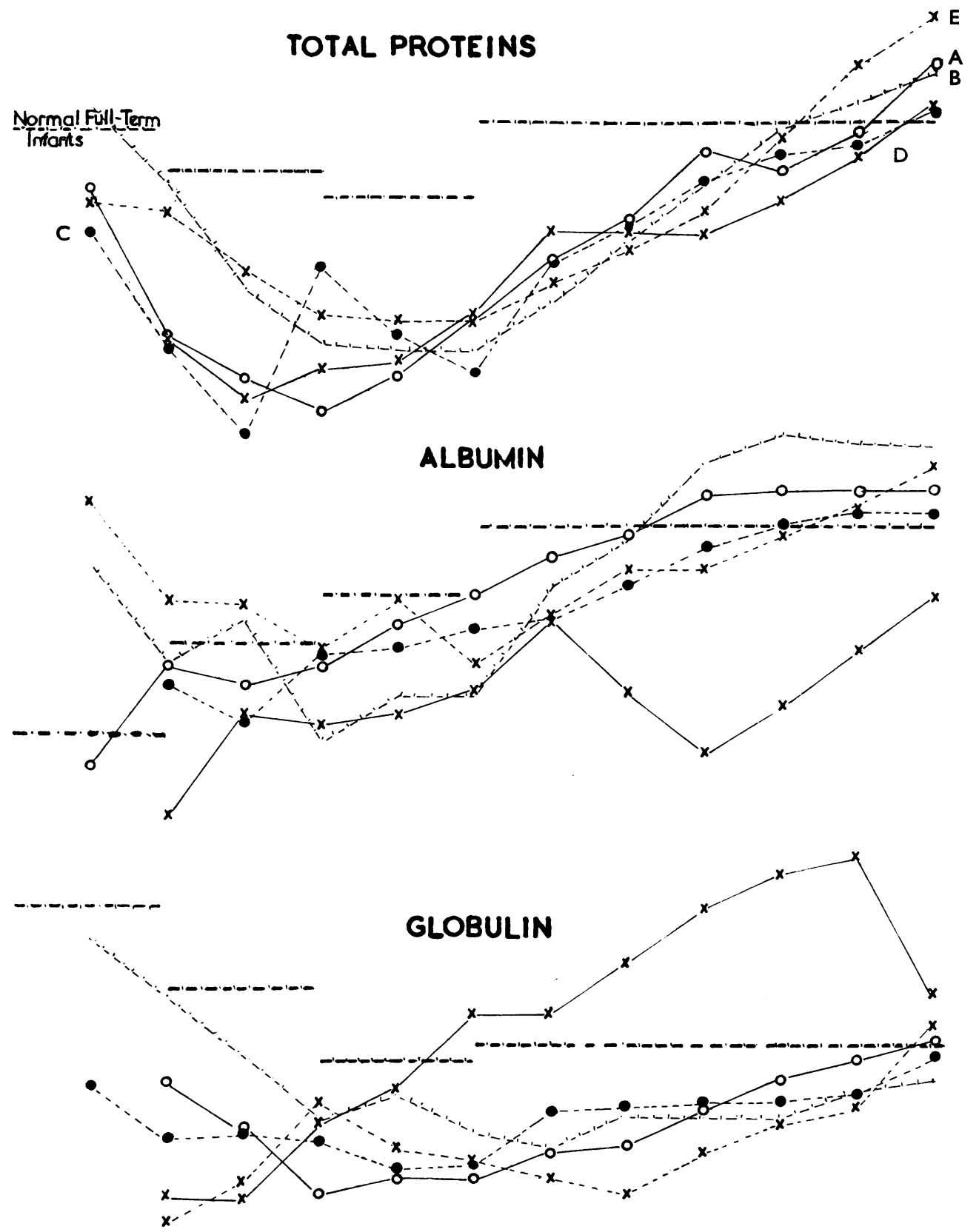

(C) $3 \frac{1}{2}-4$ lb. (1,588-1,814 g.)

A $\bigcirc \longrightarrow$ Human milk; B -1-1-1- Evaporated low protein; C $\bullet---\bullet$ High-protein $\frac{1}{2}$ skimmed cow's milk; $D \times \longrightarrow x$ Human milk + Casydrol; E x - _ - x Low-protein cow's milk + Casydrol.

Fig. 3. 
consistent differences in the results in babies over $3 \mathrm{lb}$. $(1,361 \mathrm{~g}$.) birth weight. In the babies with birth weight $2 \frac{1}{2}-3 \mathrm{lb}$. (1,134-1,361 g.) the evaporated milk (diet B) and human milk with added protein (diet D) showed the worst results, viz., a very low total protein and such foods should probably be considered unsuitable for very small infants. There was apparently little difference between the other three diets. It must be borne in mind, however, that when the babies reached a weight of $4 \frac{1}{2} \mathrm{lb}$. $(2,042 \mathrm{~g}$.) the food was sometimes changed as indicated earlier in this paper, but it is interesting to note that before the change was made the protein levels had already started to rise. The very low total protein levels reached by the group with birth weight to $2 \frac{1}{2}-3 \mathrm{lb}$. $(1,134-$ 1,361 g.) may have been due to protein insufficient in amount for very small premature children in the case of those fed on evaporated milk (diet B), or of unsuitable quality when protein was added to human milk (diet D).

In relation to the blood serum protein levels it would appear that human milk provides sufficient protein for the needs of the premature baby since the curves for the babies fed on human milk maintained a consistently good level throughout the 12 weeks of observation.

Albumin. The levels of the total proteins are obviously related to the levels of the albumin rather than the globulin, for the total protein curves and the albumin curves showed somewhat similar falls and rises. It is interesting to note that while the albumin in normal full-term infants rises continually from birth, there was a definite fall in the albumin level of the premature babies under observation particularly amongst the group with birth weight of $2 \frac{1}{2}$ to $3 \mathrm{lb}$. $(1,134-1,361 \mathrm{~g}$.) but in spite of this all groups made good progress between eight and 12 weeks and by this time had reached the levels found for normal full-term infants of the same age. Again the type of food seems to make little difference to the final results except in the case of the smallest babies fed on low-protein cow's milk whose serum albumin reached the lowest levels recorded.

Globulin. The level of globulin at birth was low compared with normal full-term infants, particularly during the first two weeks, and maintained rather a low level steadily throughout the period of observation, being little affected by the diet. The continuous subnormal level may account to some extent for the increased susceptibility of the premature baby to infection.
Results in Infants with Birth Weight under $2 \frac{1}{2} \mathrm{lb}$. $(1,134$ g.). Although it was not possible to obtain blood very regularly, especially in the early weeks of life, such results as were obtained on 13 babies with birth weight between 2 and $2 \frac{1}{2} \mathrm{lb}$. (907-1,134 g.) and one baby with a birth weight of $1 \mathrm{lb} .14 \mathrm{oz}$. ( 852 g.) were graphed on a large scale. The curves were very erratic and confused and are not reproduced here. There is little doubt that the erratic levels were partially due to small transfusions which were frequently given to those tiny babies in the early days of life. However, it became clear that on the whole there was not a great difference between the actual levels of total protein on any of the diets, though they all reached considerably lower levels at about 6 weeks of age than the group of babies with birth weight of $2 \frac{1}{2}$ to $3 \mathrm{lb}$. $(1,134-1,361 \mathrm{~g}$.) and remained at a lower level for more than 12 weeks. The albumin levels and globulin also fell to much lower levels than those in the $2 \frac{1}{2}-3 \mathrm{lb}$. $(1,134-1,361 \mathrm{~g}$.) weight group. The lowest curves were shown by the one baby on low-protein evaporated cow's milk and one on breast milk with added casein hydrolysate and this is probably another indication that these are undesirable foods for very small premature infants.

\section{Summary}

Clinical and biochemical observations have been made on 152 babies weighing less than $4 \mathrm{lb}$. at birth to determine which of five selected diets gave the best result judged by the rate of gain in weight, serum protein and haemoglobin levels, infection and mortality rates. These babies were also examined for the presence of rickets and for retrolental fibroplasia.

Babies fed on human milk have been compared with babies fed on (a) human milk reinforced with hydrolysed casein, (b) a low-protein cow's milk mixture (diluted evaporated milk), (c) a cow's milk mixture with a high-protein content (half-skimmed dried milk) and a high-protein cow's milk mixture in which part of the protein was hydrolysed (diluted evaporated milk reinforced with hydrolysed casein). The fat content of all three cow's milk mixtures was the same and all five diets had equal caloric values.

Weight. The quickest return to birth weight was achieved by babies fed on the half-skimmed dried milk. Those fed on human milk did almost as well (and indeed human milk was often the only food well tolerated by infants under $2 \mathrm{lb}$. (907 g.) at birth), while those fed on the low-protein evaporated cow's milk mixture did not do so well. The addition of casein hydrolysate was badly tolerated by infants 
weighing less than $2 \frac{1}{2} \mathrm{lb}$. $(1,134 \mathrm{~g}$.) at birth. Over this weight, the added protein appeared to reduce the time taken by babies fed on the low-protein evaporated cow's milk mixture but the time was not reduced when hydrolysed protein was added to human milk.

The rate of subsequent gain in hospital was very similar in all babies weighing more than $3 \frac{1}{2} \mathrm{lb}$. $(1,588 \mathrm{~g}$.) at birth, irrespective of diet. Below this birth weight the most rapid progress was made by babies fed on half-skimmed dried milk but it is likely that this was largely due to excessive water retention, because the majority of these babies developed slight pitting oedema. Human milk gave almost as good results except in the small group weighing less than $2 \frac{1}{2} \mathrm{lb}$. $(1,134 \mathrm{~g}$. $)$ at birth. The least rapid gains were found among babies fed on the low-protein evaporated cow's milk mixture. Generally speaking, the addition of hydrolysed casein to human milk and to the low-protein evaporated cow's milk mixture did not improve the rate of gain.

After discharge from hospital breast-fed babies gained more rapidly than those fed on cow's milk. Babies fed on a low-protein cow's milk mixture gained the least rapidly.

Anaemia. During their stay in hospital the highest proportion of babies requiring transfusion was among those fed on the low-protein cow's milk diet. The proportions requiring transfusion were similar among babies fed on human milk and the three high-protein diets.

Incidence of Infection. Babies fed on human milk had the lowest incidence of major infections while in hospital, followed closely by babies fed on the half-skimmed dried milk. Babies fed on the lowprotein evaporated cow's milk mixture had the highest infection rate during this period. After discharge and until the age of 6 months, there were no major infections among the 12 breast fed infants, but three out of 30 of those fed on the low-protein evaporated cow's milk mixture and seven out of 32 of those fed on the half-skimmed dried milk had developed such infections.

Mortality. During their stay in hospital three babies who were fed on the low-protein evaporated cow's milk mixture died of infection. After discharge, there were 10 deaths before the age of 1 year among the 140 babies fed on cows' milk mixtures, while there were no deaths among the 12 breast-fed infants. These figures are obviously not statistically significant, but one of us (Crosse, 1952) has shown similar results for large numbers of babies.
Rickets. A parallel investigation, which included some of the babies in this study, indicated that babies on human milk showed less tendency to develop rickets than babies fed on cow's milk, when they were given adequate supplements of vitamins, calcium and phosphorus.

Retrolental Fibroplasia. Five babies in this investigation developed retrolental fibroplasia. One had been fed on human milk, two on the lowprotein evaporated cow's milk mixture and two on human milk with added casein hydrolysate but there were no signs of abnormality until two or three weeks after the diets had been changed to undiluted half-skimmed cow's milk (half-skimmed dried milk 1 in 8). The first signs of abnormality usually coincided with the development of oedema. All five babies had received oxygen for periods varying from 18 to 30 days, these trials having been carried out before the relevance of oxygen had been recognized.

Serum Protein Levels. Total protein levels were always below the normal level for full-term infants during the first 12 weeks of life except in the case of babies with birth weights of $3 \frac{1}{2}$ to $4 \mathrm{lb}$. $(1,588 \mathrm{~g}$.$1,814 \mathrm{~g}$.) who reached normal levels between 10 and 12 weeks. Among babies with birth weights of over 3 lb. $(1,361 \mathrm{~g}$.) diet made little difference but under this weight the curves for babies fed on the lowprotein evaporated cow's milk mixture and on human milk with added casein hydrolysate reached the lowest levels.

The albumin levels fell for a few weeks after birth instead of rising as in the full-term infant. Normal levels were reached at about the age of 8 weeks among babies over $3 \frac{1}{2} \mathrm{lb}$. (1,588 g.) but not until 12 weeks or more among those weighing less than $3 \frac{1}{2} \mathrm{lb}$. $(1,588 \mathrm{~g}$.). The lowest levels were found among the smallest babies fed on the lowprotein evaporated cow's milk mixture. There was little difference between the curves for other diets.

The globulin levels were nearly all below the levels for full-term babies, especially during the first two weeks of life, and tended to maintain a constant level. Diet appeared to make little difference.

\section{Conclusions}

We cannot subscribe to the opinion of those who state that human milk is unsuitable or inferior for premature babies. It is the food which is best tolerated by the smallest babies during the first few weeks of life and by sick premature babies. The return to the birth weight is not prolonged and the 
subsequent weight curves run parallel to the in utero curve if sufficient calories are given (60 per lb. (450 g.) daily). There is no evidence to show that anaemia or hypoproteinaemia are more common among infants fed on human milk than on highprotein diets. The incidence of infection and mortality are lowest among those fed on this natural food. Provided adequate vitamin and mineral salt supplements are given, the incidence of rickets is lower among infants fed on human milk than among those fed on cow's milk. It is also possible (Hepner and Krause, 1952) that babies fed entirely on human milk are less liable to develop retrolental fibroplasia.

There is no doubt that the half-skimmed dried milk mixture produces a more rapid gain in weight during the first six to eight weeks of life, but there is good reason to believe that this is mainly due to increased water retention and not true growth. If human milk cannot be obtained, half-skimmed dried milk is a fairly good substitute. This diet gives similar results to those obtained with human milk in regard to haemoglobin and serum protein levels; the hospital infection rate among babies fed in this way was similar to that among babies fed on human milk but after discharge from hospital seven of the 32 babies fed on half-skimmed milk developed major infections while the 12 breast-fed babies remained free from infection. There may be an increased risk of retrolental fibroplasia due to the high electrolytic content.

We have found ample evidence to support the suggestion of Young et al. (1950) that cow's milk with a protein content similar to human milk might not be a good food for premature babies. Babies fed on the low-protein evaporated cow's milk diet showed the slowest return to birth weight and the least rapid subsequent rate of gain, the highest proportion of babies requiring transfusion, the lowest serum protein levels and the highest hospital infection rate. The low-protein evaporated cow's milk mixture did not appear to supply sufficient protein of the correct quality to meet the needs of a premature baby. The addition of casein hydrolysate to the low-protein cow's milk mixture tended to minimize the disadvantages of this diet, but was not always well tolerated by small infants during the early days of life.
Contrary to the findings of Jorpes et al. (1946) the addition of casein hydrolysate to human milk gave worse results than unfortified human milk in relation to time taken to regain the birth weight (this was due to intolerance of the added protein by some of the smaller babies), serum protein levels, incidence of hospital infection and mortality rate.

In our opinion, human milk is the best food for premature babies. In the absence of an adequate supply of human milk, it would appear that the best substitute is a cow's milk mixture with a protein content considerably higher than that found in human milk, and that there is no need for this protein to be hydrolysed. There would however appear to be a case for the use of a half-skimmed milk with a lower electrolyte content in view of the excessive hydration of babies on this food and the possibility of an increased liability to develop retrolental fibroplasia due to this cause. There is plenty of evidence to suggest that a cow's milk mixture with a low-protein content should not be used for premature babies.

The authors wish to acknowledge the valuable assistance of the Sister-in-Charge of the Premature Baby Unit and her staff and to thank them for their interest and cooperation in the work; also to thank Mr. J. Gregory Williamson for the reproductions of the graphs.

Miss Aubrey held a Cow-and-Gate Fellowship in the Department of Paediatrics and Child Health of the University of Birmingham and was responsible for most of the chemical estimations. This award is gratefully acknowledged.

We are indebted to Professor J. M. Smellie for valuable criticism and support.

\section{REFERENCES}

Broadbent, I. and Finch, E. (1950). Archives of Disease in Childhood, 25, 134.

Crosse, V. M. (1952). The Premature Baby, 3rd ed. London.

Ford, F. J. (1949). Lancet, 1, 987.

Gordon, H. H. and Levine, S. Z. (1944). J. Pediat., 25, 464 - and McNamara, H. (1941). Amer. J. Dis. Child., 62, 328. - Levine, S. Z. and McNamara, H. (1947). Ibid., 73, 442. -, Levine, S. Z. and McNamara, H. (1947). Ibid., 73, 442.

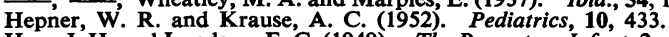
Hess, J. H. and Lundeen, E. C. (1949). The Premature Infant, 2 nd ed. Philadelphia.

Jorpes, J. E., Magnusson, J. H. and Wretlind, A. (1946). Lancet, 2, 228.

Mackay, H. M. M. and Levin, B. (1953). Archives of Disease in Childhood, 28, 245.

Poyner-Wall, P. and Finch, E. (1950). Ibid., 25, 129.

Sydow, G. von. (1946). Acta Paediat., stockh., 33, Suppl. 2, p. 101

Young, W. F., Hallum, J. L. and McCance, R. A. (1941). Archives of Disease in Childhood, 16, 243.

Poyner-Wall, P., Humphreys, H. C., Finch, E. and Broadbent, I. (1950). Ibid., 25, 31. 